\title{
Dopamine Decreases the Excitability of Layer V Pyramidal Cells in the Rat Prefrontal Cortex
}

\author{
Allan T. Gulledge and David B. Jaffe \\ Division of Life Sciences, University of Texas at San Antonio, San Antonio, Texas 78249
}

In both primates and rodents, the prefrontal cortex (PFC) is highly innervated by dopaminergic fibers originating from the ventral tegmental area, and activation of this mesocortical dopaminergic system decreases spontaneous and evoked activity in the PFC in vivo. We have examined the effects of dopamine (DA), over a range of concentrations, on the passive and active membrane properties of layer $\mathrm{V}$ pyramidal cells from the rat medial PFC (mPFC). Whole-cell and perforated-patch recordings were made from neurons in rat mPFC. As a measure of cell excitability, trains of action potentials were evoked with 1-seclong depolarizing current steps. Bath application of DA (0.05-30 $\mu \mathrm{M})$ produced a reversible decrease in the number of action potentials evoked by a given current step. In addition, DA reversibly decreased the input resistance $\left(R_{N}\right)$ of these cells. In a subset of experiments, a transient increase in excitability was observed after the washout of DA. Control experiments suggest that these results are not attributable to changes in spontaneous synaptic activity, age-dependent processes, or strain-specific differences in dopaminergic innervation and physiology. Pharmacological analyses, using D1 agonists (SKF 38393 and SKF 81297), a D1 antagonist (SCH 23390), a D2 receptor agonist (quinpirole), and a D2 antagonist (sulpiride) suggest that decreases in spiking and $R_{\mathrm{N}}$ are mediated by D2 receptor activation. Together, these results demonstrate that DA, over a range of concentrations, has an inhibitory effect on layer $\mathrm{V}$ pyramidal neurons in the rat $\mathrm{mPFC}$, possibly through D2 receptor activation.

Key words: dopamine; prefrontal cortex; electrophysiology; pyramidal cell; whole-cell recording; perforated-patch recording
The prefrontal cortex (PFC) is an area of associational cortex important for a form of short-term information storage often described as "working memory" (Funahashi et al., 1991). In addition to receiving excitatory input from the thalamus (Condé et al., 1990), the hippocampus (Carr and Sesack, 1996), and other cortical areas (Condé et al., 1995), the rat medial PFC (mPFC), like the dorsolateral PFC of primates, is highly innervated by dopaminergic projections from the ventral tegmental area (VTA) (Bjorklund et al., 1978; Emson and Koob, 1978; Brown et al., 1979; Descarries et al., 1987). In both primates and rats, this mesocortical dopamine (DA) system is important for the learning of delay-dependent memory tasks (Brozoski et al., 1979; Simon et al., 1980; Bubser and Schmidt, 1990; Sawaguchi and GoldmanRakic, 1991).

A number of investigations have examined the influence of DA on neuronal activity in rat $\mathrm{mPFC}$ in vivo. Stimulation of dopaminergic cells in the VTA depresses both thalamically evoked and spontaneous mPFC activity (Ferron et al., 1984; Mantz et al., 1988; Pirot et al., 1992), and this effect can be blocked by 6-OHDA lesions (Ferron et al., 1984). Similar depression of spontaneous cell firing in the rat mPFC and other frontal cortical areas has been observed in response to iontophoretic application of DA (Bernardi et al., 1982; Pirot et al., 1992).

Although the in vivo data suggests that DA has a general inhibitory effect on PFC activity, there has been much less consensus regarding the effect of DA on the excitability of individual

\footnotetext{
Received June 15, 1998; revised Aug. 19, 1998; accepted Aug. 21, 1998.

This work was supported by the National Institute of General Medical Sciences Grant GM0P194-1751.

Correspondence should be addressed to David B. Jaffe, Division of Life Sciences, University of Texas at San Antonio, 6900 North Loop 1604 West, San Antonio, TX 78249.

Copyright (ㄷ) 1998 Society for Neuroscience $\quad 0270-6474 / 98 / 189139-13 \$ 05.00 / 0$
}

neurons as assessed in vitro. In one study, low concentrations of DA $(0.1-10 \mu \mathrm{M})$ decreased the number of spikes evoked by depolarizing current steps (Geijo-Barrientos and Pastore, 1995), whereas in three other reports, higher concentrations of DA (2-50 and $400 \mu \mathrm{M}$ ) produced an increase in excitability (Penit-Soria et al., 1987; Yang and Seamans, 1996; Shi et al., 1997).

A number of recent studies in both primates and rodents suggest that there is a critical concentration of DA required for normal PFC function (Brozoski et al., 1979; Sawaguchi and Goldman-Rakic, 1994; Murphy et al., 1996; Zahrt et al., 1997); if DA levels are too high or too low, there will be significant cognitive deficits. It is therefore a reasonable hypothesis that the cellular effects of DA in the mPFC are concentration-dependent (Zahrt et al., 1997). For example, low concentrations of DA might enhance neuronal excitability, whereas high levels may result in depression. In this study, we have used whole-cell and perforatedpatch recording techniques to measure the effect of DA on the active and passive membrane properties of layer $\mathrm{V}$ pyramidal cells in the rat mPFC. We report that DA, over a range of concentrations, depresses the excitability of layer $\mathrm{V}$ pyramidal neurons in rat mPFC. Our experiments also suggest that this depression is mediated via D2 receptor activation.

A preliminary report has been presented in abstract form (Gulledge and Jaffe, 1997).

\section{MATERIALS AND METHODS}

Brain slices. Coronal slices $(300 \mu \mathrm{m})$ containing $\mathrm{mPFC}$ were harvested with a vibratome from 17- to 30-d-old Sprague Dawley rats (Harlan, Indianapolis, IN) in cold $\left(4^{\circ} \mathrm{C}\right)$ artificial CSF (aCSF) containing (in mM): 124 choline chloride, $26 \mathrm{NaHCO}_{3}, 2.5 \mathrm{KCl}, 1.25 \mathrm{Na}_{2} \mathrm{HPO}_{4}, 2 \mathrm{MgCl}_{2}, 2$ $\mathrm{CaCl}_{2}$, and 10 dextrose. For some experiments, slices were harvested from either larger 10-week-old Sprague Dawley rats or 20- to 30-d-old Long-Evans rats (Charles River, Wilmington, MA). Only coronal sections anterior to and no more than $2 \mathrm{~mm}$ away from the genu of the 
corpus callosum were used for this study. Slices were allowed to incubate for at least $1 \mathrm{hr}$ at room temperature $\left(\sim 23^{\circ} \mathrm{C}\right)$ in aCSF in which $\mathrm{NaCl}$ replaced choline chloride. Slices were transferred as needed into a submerged recording chamber perfused with oxygenated aCSF $(\sim 2$ $\mathrm{ml} / \mathrm{min}$ ). All aCSF solutions were oxygenated continuously with $95 \%$ $\mathrm{O}_{2}-5 \% \mathrm{CO}_{2}$. In some experiments, the aCSF contained picrotoxin $(10 \mu \mathrm{M})$ and kynurenate $(1 \mathrm{mM})$ to block fast synaptic transmission. Experiments were performed at room temperature $\left(\sim 23^{\circ} \mathrm{C}\right)$ unless otherwise noted.

Electrophysiology. Whole-cell and perforated-patch recordings were made from visually identified layer $\mathrm{V}$ pyramidal cells from the $\mathrm{mPFC}$ using infrared video differential interference contrast (DIC) microscopy (Stuart et al., 1993) with a $40 \times$ water-immersion objective. To ensure that these cells did not have cut apical dendrites, we positioned our slices such that the apical dendrites were either in the same plane as the soma or descended into the slice. Several cells were filled with biocytin for postexperiment verification of dendritic presence (see Fig. 1B) (Chitwood et al., 1997). Patch pipettes (2-5 M $\Omega$ ) were filled with (in mM): 120 K-gluconate, 10 HEPES, 0.1 EGTA, $20 \mathrm{KCl}, 2 \mathrm{MgCl}_{2}, 3 \mathrm{Na}_{2} \mathrm{ATP}$, and $0.3 \mathrm{NaGTP}, \mathrm{pH}$ 7.3. Perforated-patch recordings were made by adding nystatin to the pipette solution (final concentration was $500 \mu \mathrm{g} / \mathrm{ml}, 0.30 \%$ DMSO).

Current-clamp recordings were made using an AxoClamp 2B amplifier (Axon Instruments, Foster City, CA) and were digitized at 1 or $3 \mathrm{kHz}$ using an ITC-16 interface (Instrutech, Great Neck, NY) connected to a Power Macintosh 8100 computer running AxoData (Axon Instruments) acquisition software. Whole-cell pipette series-resistance $\left(R_{\mathrm{S}}\right)$ was less than $20 \mathrm{M} \Omega$ and was bridge compensated. Analyses of electrical responses were performed using custom software written with Igor Pro (Wavemetrics, Lake Oswego, OR). Only one neuron experiencing a single drug treatment was used from each brain slice. In all cases, only cells with a resting potential of at least $-60 \mathrm{mV}$ and stable baseline responses were given drug treatments.

Experimental paradigm. To measure cell excitability, action potentials were evoked by 1-sec-long depolarizing current injections (100-400 pA) at $0.1 \mathrm{~Hz}$. Input resistance $\left(R_{\mathrm{N}}\right)$ was determined from linear regression in the linear range (generally $\pm 10 \mathrm{mV}$ from resting potential) of the voltage-current relationship established by plotting the steady-state voltage change in response to a series of depolarizing and hyperpolarizing current injections (see Fig. $2 C, D$ ). After baseline measurements of action potential number and $R_{\mathrm{N}}$, DA $(0.01-30 \mu \mathrm{M})$ was bath applied for $\sim 5 \mathrm{~min}$. Two gravity-fed perfusion lines were used to change solutions. New solutions reached the recording chamber in $<1 \mathrm{~min}$, as determined by exchanging water with a dyed solution, and reached full concentration in $\sim 2$ min. Although complete washout from the chamber took between 10 and $12 \mathrm{~min}$, the majority of dye was removed after $5 \mathrm{~min}$. Both control and drug aCSF were continuously oxygenated throughout experiments. Ascorbate $(1 \mu \mathrm{M})$ and nomifensine $(1 \mu \mathrm{M})$ were added to all DA solutions to reduce oxidation and to prevent DA uptake into dopaminergic fibers, respectively.

Experimentally produced changes in membrane potential $\left(V_{\mathrm{m}}\right)$ were compensated with a bias current to maintain $V_{\mathrm{m}}$ at baseline levels. The bias current was removed where noted. Stock solutions of all drugs were made fresh daily and mixed into oxygenated aCSF as needed. Dopaminergic agonists and antagonists were obtained from Research Biochemicals (Natick, MA). Other substances were purchased from Sigma (St. Louis, MO).

Analysis and statistics. For each cell, the number of spikes evoked by depolarizing current steps was quantified by averaging the number of spikes produced in five consecutive traces immediately before, at the end of, and 5 min after drug application. Furthermore, for cells that showed a change in evoked spikes during a given drug treatment, only those that exhibited a reversible effect (a washout of at least $50 \%$ of the effect) were used for analysis to ensure that the effect was not caused by a general rundown. Numerical values are expressed as mean \pm SEM. In most experiments, the effects of DA or DA agonists were compared with controls using a Student's $t$ test for unpaired samples. "Within-cell" comparisons used a Student's $t$ test for paired samples where noted. Comparisons of dopaminergic effects across concentrations were made using a one-way ANOVA.

\section{RESULTS}

We examined the effects of bath-applied DA or DA agonists on visually identified layer $\mathrm{V}$ pyramidal cells from the anterior cingulate and prelimbic areas of the rat dorsal mPFC (Fig. 1A).

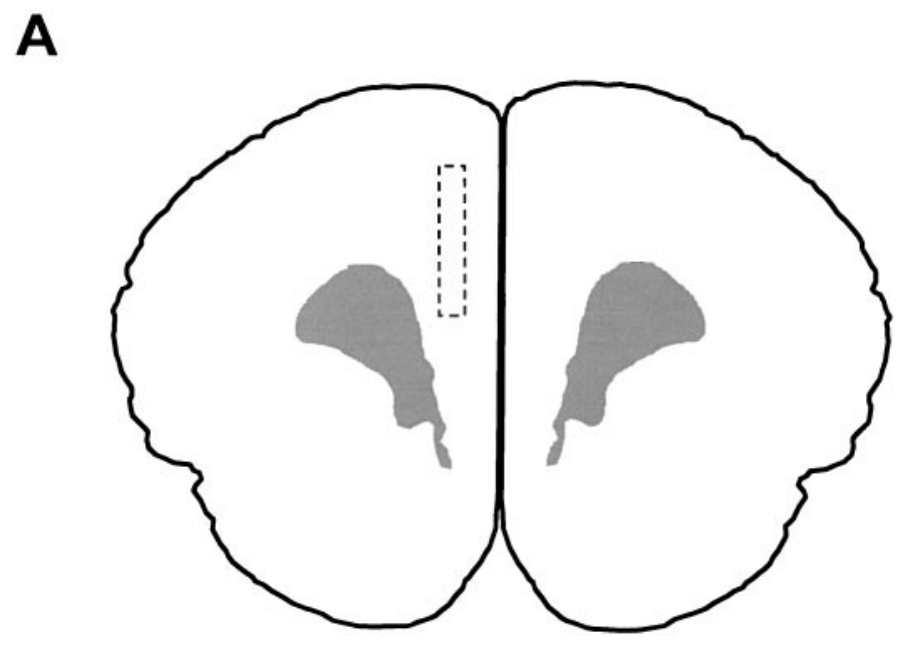

\section{B}

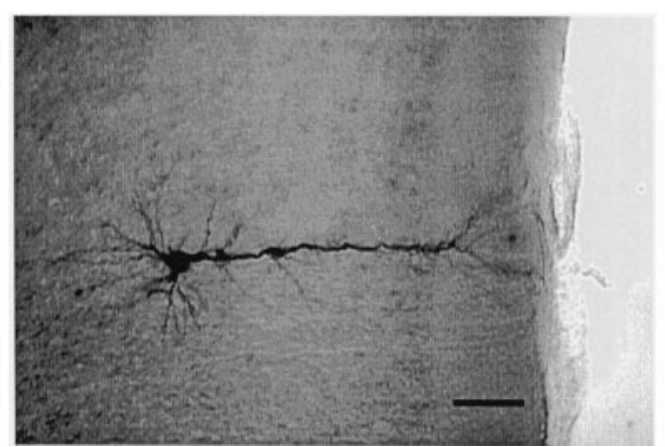

Figure 1. Location and morphology of recorded cells. A, Illustration of a coronal slice that includes the mPFC. The box shows the area in which cells for this study were patched. Shaded areas denote corpus callosum. $B$, Photomicrograph of a biocytin-labeled layer V pyramidal cell from the rat mPFC. Scale bar, $100 \mu \mathrm{m}$.

These neurons were identified using DIC video microscopy by their large pyramidal-shaped somas ( $\geq 20 \mu \mathrm{m}$ diameter) and by the presence of long apical dendrites extending toward the pial surface (Fig. 1B). Of 53 cells for which the dorsoventral position was recorded, $68 \%$ were identified as prelimbic because of their position below the dorsal peak of the forceps minor of the corpus callosum. The remainder of these cells was from the anterior cingulate. Baseline physiology and responses to DA were similar in cells from both regions.

Once selected, patch electrodes were sealed onto the somas of these cells for whole-cell or perforated-patch recording. In response to suprathreshold current steps (1 sec duration), these cells exhibited modest spike frequency accommodation, often after an initial spike "doublet" (see Figs. $2 A, 6 A, 7 A$ ). Doublets were observed in $75 \%$ of recorded cells. This firing pattern was similar to the "intrinsic bursting" cells reported by Yang et al. (1996). Furthermore, when single spikes were evoked, these same cells regularly demonstrated depolarizing afterpotentials (data not shown) (Yang et al., 1996; Haj-Dahmane and Andrade, 1997). Burst firing, corresponding to "repetitive oscillatory bursting" cells (Yang et al., 1996), was only observed in six cells. 


\section{Effect of DA on neuron excitability}

The effect of bath-applied DA on the excitability of layer $\mathrm{V}$ pyramidal cells was studied by measuring changes in spike number in response to a 1-sec-long depolarizing current injection. The amplitude of the injected current (100-400 pA) was adjusted to evoke approximately six action potentials (the mean number of baseline action potentials was $6.1 \pm 0.1$ spikes; $n=119)$. After 2-5 min of baseline measurements, DA $(0.01-30 \mu \mathrm{M})$ was bath applied for $\sim 5 \mathrm{~min}$, followed by a 5-10 min washout period. In 39 of 41 cells $(95 \%)$, we observed a reversible decrease in the number of evoked spikes (Fig. $2 A$ ). The mean decrease in action potential number for all cells was $57 \pm 4 \%(n=41)$. In one experiment, there was a nonreversible increase in evoked spikes during DA treatment (an increase from seven to eight spikes in 10 nM DA), whereas in another cell DA had no effect. An effect of DA on the number of evoked spikes could be seen within 2 min after the onset of DA application (Fig. 2B). Biphasic responses to DA (i.e., transient increases in spike number preceding depression) were not observed during drug application.

In control experiments, 5 min treatment (after 2-5 min of baseline measurements) with $1 \mu \mathrm{M}$ ascorbate and $1 \mu \mathrm{M}$ nomifensine alone decreased the number of evoked spikes by $11 \pm 6 \%$ $(n=7)$. This change from baseline was neither reversible nor significant $(\mathrm{df}=6 ; t=1.7 ; p>0.05$; Student's $t$ test for paired samples). The reduction in spike number produced by DA was significantly different from changes observed in controls ( $\mathrm{df}=46$; $t=4.3 ; p<0.05)$. When grouped according to the concentration of DA applied, significant decreases in spike number were observed at DA concentrations $>10 \mathrm{~nm}$ (Fig. $3 A$ ). There was, however, no dose dependence at concentrations between $50 \mathrm{~nm}$ and $30 \mu \mathrm{M}(\mathrm{df}=35 ; F=0.92 ; p>0.05$; ANOVA $)$.

DA produced a reversible depression of excitability over a wide range of current intensities (Fig. 4A). In six of seven cells, the number of spikes produced by varying levels of depolarizing current injection was reversibly depressed by the addition of DA $(30 \mu \mathrm{M})$ to the aCSF. Doublets were observed at the beginning of spike trains in all of these cells, although the current intensities needed to generate them varied from cell to cell. In the presence of DA, the amount of current required to trigger doublets was significantly increased by $9.1 \pm 1.5 \%(\mathrm{df}=6 ; t=5.3 ; p<0.05$; Student's $t$ test for paired samples). The increase in threshold for doublet generation was reversible after the washout of DA, and in six of seven cells, less current was required for doublet expression after DA treatment than was required in baseline conditions.

During more prolonged exposures to DA (15-20 $\mathrm{min})$, the effect of $10 \mu \mathrm{M}$ DA on excitability was unstable; after an initial decrease in the number of spikes, the membrane excitability transiently returned to near baseline levels without overshooting (data not shown). Repeatedly, DA produced a transient depression in spike number. This oscillatory response had a period of $\sim 5 \mathrm{~min}$ and lasted for the duration of DA application $(n=4)$.

We also monitored the $R_{\mathrm{N}}$ of 30 of the 48 cells referred to above before, during, and after DA treatment, as described (Fig. $2 C, D)$. The initial $R_{\mathrm{N}}$ for these neurons was $111 \pm 5 \mathrm{M} \Omega$. Bath application of DA produced a reversible decrease of $R_{\mathrm{N}}$ in 24 of the 30 cells $(80 \%)$. The mean decrease in $R_{\mathrm{N}}$ was $11 \pm 2 \%(n=$ $30)$. This was significantly different from changes observed in control cells $(n=7)$, which showed only a $2 \pm 3 \%$ decrease in $R_{\mathrm{N}}$ ( df $=35 ; t=2.7 ; p<0.05)$. Significant decreases in $R_{\mathrm{N}}$ were observed at DA concentrations between $50 \mathrm{nM}$ and $1 \mu \mathrm{M}$. Interestingly, unlike changes in action potential number, an inverted
"U-shaped" dose dependence was observed for $R_{\mathrm{N}}$. At $30 \mu \mathrm{M}, \mathrm{DA}$ had no significant effect on $R_{\mathrm{N}}$. Changes in $R_{\mathrm{N}}$ for cells treated with $30 \mu \mathrm{M}$ DA were significantly different from those treated with concentrations between $50 \mathrm{nM}$ and $1 \mu \mathrm{M}(\mathrm{df}=26 ; F=6.3$; $p<0.05$; ANOVA)

Because decreases in $R_{\mathrm{N}}$ will tend to reduce the number of spikes evoked by depolarizing current injections, we tested whether there was a correlation between changes in $R_{\mathrm{N}}$ and the number of evoked action potentials (Fig. $4 B$ ). As expected, there was a significant correlation between changes in evoked spikes and changes in $R_{\mathrm{N}}\left(r^{2}=0.27 ; n=88 ; p<0.05\right)$. This suggests that DA-induced changes in $R_{\mathrm{N}}$ may contribute, at least in part, to the inhibition of pyramidal neuron firing.

\section{Control experiments}

The results described above conflict with a number of previous reports (Table 1 ) on the effects of $\mathrm{DA}$ on layer $\mathrm{V}$ pyramidal neurons in rat mPFC (Penit-Soria et al., 1987; Yang and Seamans, 1996; Shi et al., 1997). In an attempt to account for why our results differed so significantly from Yang and Seamans (1996) and to possibly resolve any differences in experimental procedures, the following control experiments were performed.

\section{Absence of synaptic transmission}

Inhibitory neurons in mPFC that synapse onto layer $\mathrm{V}$ pyramidal cells (Houser et al., 1983; Kawaguchi, 1993; Kawaguchi and Kubota, 1993) express DA receptors (Vincent et al., 1993) and may exhibit DA-induced changes in cell excitability (Penit-Soria et al., 1987; Yang et al., 1997; Zheng et al., 1997). Because spontaneous synaptic input can modulate the passive properties of neurons (Sah et al., 1989; Softky and Koch, 1993), we tested the hypothesis that DA reduces the excitability of layer $\mathrm{V}$ pyramidal cells by increasing spontaneous synaptic transmission. We added the nonselective ionotropic glutamate receptor antagonist kynurenate $(1 \mathrm{~mm})$ and the $\mathrm{GABA}_{\mathrm{A}}$ receptor blocker picrotoxin $(10 \mu \mathrm{M})$ to the aCSF before the application of $500 \mathrm{~nm}$ DA to block fast excitatory and inhibitory synaptic input (Fig. 5). Under these conditions $(n=6)$, DA still produced a significant decrease in the number of evoked spikes of $60 \pm 12 \%(\mathrm{df}=11 ; t=3.6 ; p<0.05)$ (Fig. $5 A, B)$. Consistent with our previous experiments, $R_{\mathrm{N}}$ was also significantly reduced by $18 \pm 3 \%(\mathrm{df}=11 ; t=4.0 ; p<0.05)$ (Fig. $5 C$ ). These results indicate that the effects of DA are not caused by changes in spontaneous synaptic transmission.

\section{Perforated patch experiments}

In previous investigations, sharp microelectrode recordings were used to assess the effects of DA on the excitability of layer V neurons in vitro (Penit-Soria et al., 1987; Law-Tho et al., 1994; Geijo-Barrientos and Pastore, 1995; Yang and Seamans, 1996; Shi et al., 1997). We next tested the possibility that, through the use of the whole-cell recording technique, we were unknowingly changing the internal environment of these cells sufficiently to mask other effects of DA (i.e., an increase in excitability). To control for this possibility, perforated-patch recording methods were used in 11 experiments (Fig. 6). Again, as observed with whole-cell recordings, the number of spikes evoked in the presence of $500 \mathrm{~nm}$ DA was significantly less than the number of spikes evoked in baseline conditions. The mean change observed was $-28 \pm 6 \%(\mathrm{df}=10 ; t=4.5 ; p<0.05$; Student's $t$ test for paired samples). This change, however, was not significantly different from whole-cell DA experiments. 
A

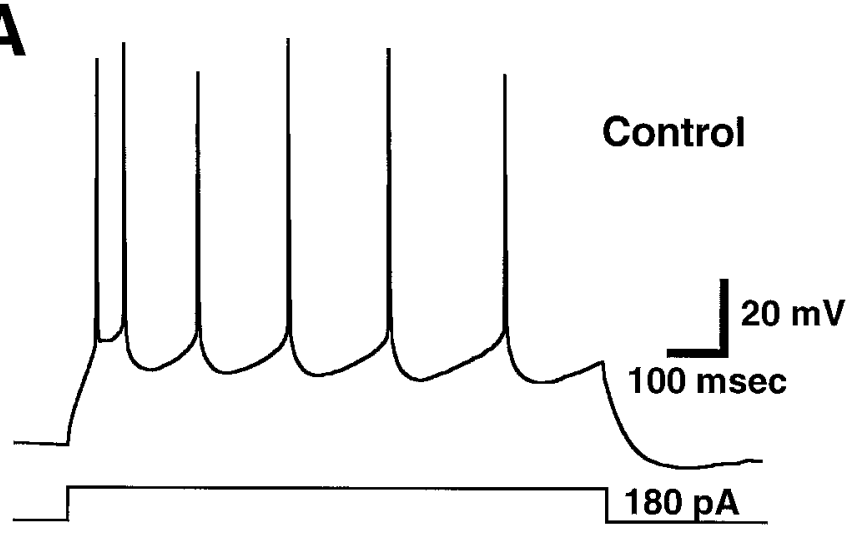

C
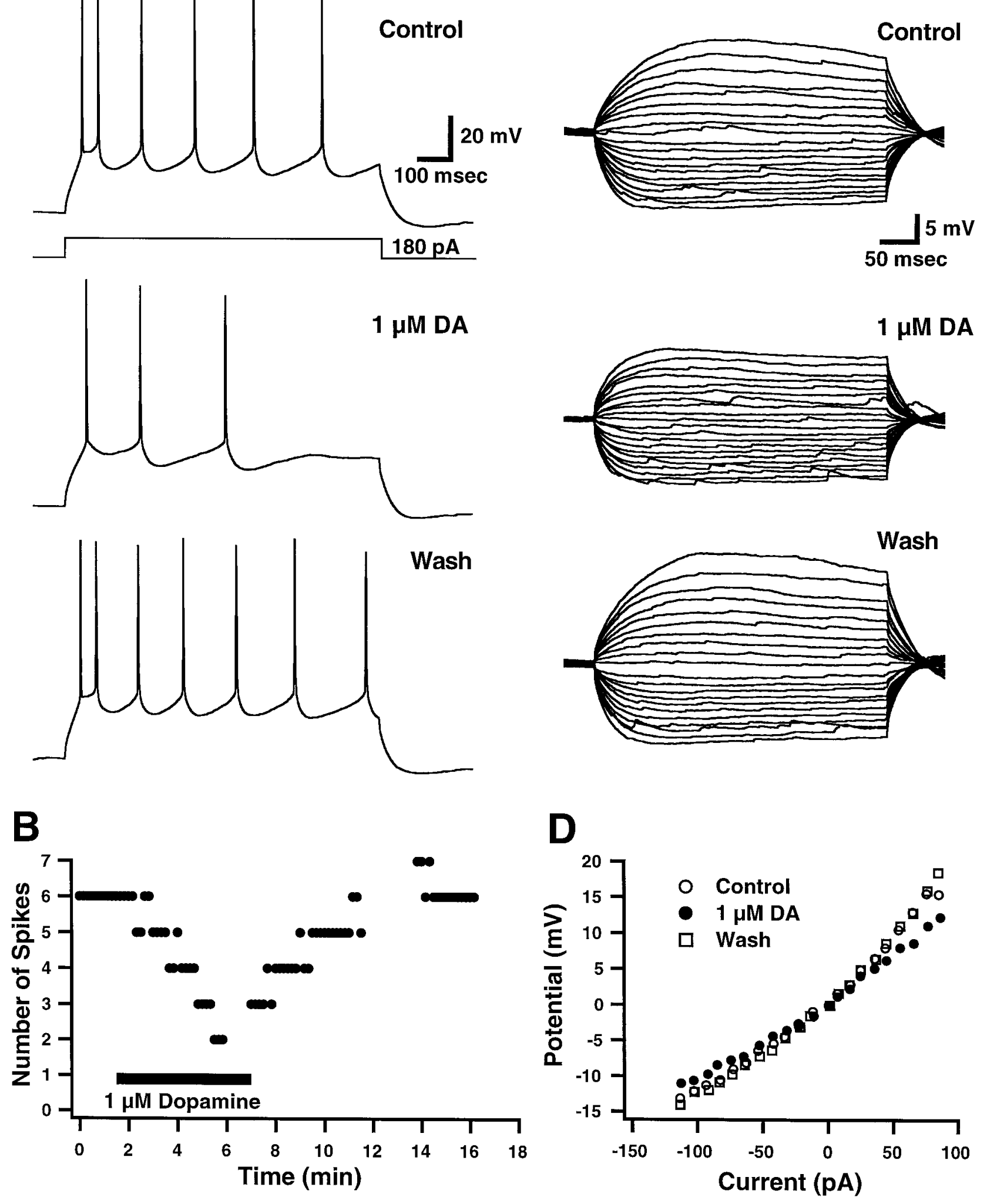

Figure 2. DA decreases the excitability of layer V pyramidal cells. $A$, Representative action potentials evoked by a 1-sec-long depolarizing current injection before (top), during (middle), and after (bottom) the bath application of $1 \mu \mathrm{M} \mathrm{DA}$. B, Time course illustrating the reduction in spike number during the application of DA. A decrease in the number of spikes is seen within 2 min of DA application. Note the transient rebound increase in the number of spikes after DA washout. $C$, Membrane response to a variety of positive and negative current steps before (top), during (middle), and after (bottom) the application of $1 \mu \mathrm{M}$ DA. D, A plot of the voltage-current relationship before (open circles), during ( filled circles), and after (open squares) DA application. All data shown are from the same layer $V$ pyramidal cell. 

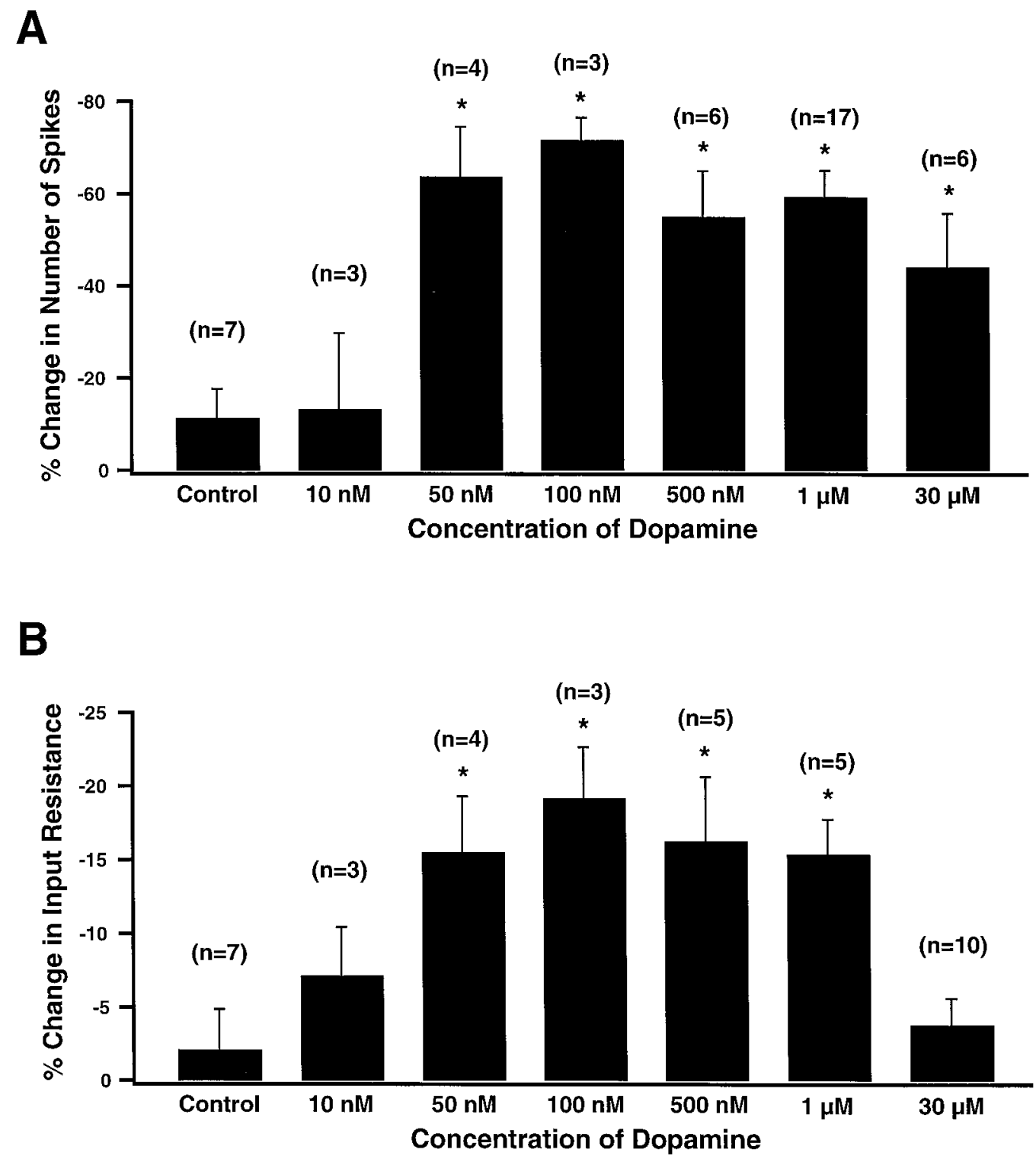

Figure 3. DA decreases the excitability of layer V pyramidal cells over a range of concentrations. $A$, Summary of the percent decrease in spike number for different DA concentrations. $B$, Summary of changes in $R_{\mathrm{N}}$ for a range of DA concentrations. For this and other figures, asterisks denote significant changes in the number of spikes and $R_{\mathrm{N}}(p<0.05)$.

\section{Experiments at $\sim 31^{\circ} \mathrm{C}$}

Most previous studies on the effects of DA on layer $\mathrm{V}$ pyramidal neuron excitability were performed at temperatures above $30^{\circ} \mathrm{C}$. This variable might affect the response of layer $\mathrm{V}$ neurons to DA. Additional experiments were conducted at $\sim 31^{\circ} \mathrm{C}$ (as opposed to room temperature, $\sim 23^{\circ} \mathrm{C}$ ). For these experiments, we chose a concentration of DA $(30 \mu \mathrm{M})$ within the range used in previous investigations (Table 1). Application of $30 \mu \mathrm{M}$ DA produced a significant and reversible depolarization of $1.8 \pm 0.4 \mathrm{mV}$ from baseline levels ( $\mathrm{df}=8 ; t=4.8 ; p<0.05$; Student's $t$ test for paired samples), which is consistent with previous reports (Penit-Soria et al., 1987; Law-Tho et al., 1994; Geijo-Barrientos and Pastore, 1995; Shi et al., 1997). Despite this modest depolarization, DA still decreased the number of evoked spikes from baseline levels by $44 \pm 12 \%(\mathrm{df}=8 ; t=3.8 ; p<0.05$; Student's $t$ test for paired samples) (Fig. $7 A, B$ ). When the membrane potential of the neu- ron was returned to baseline levels, DA reduced the number of evoked spikes by $88 \pm 6 \%(\mathrm{df}=8 ; t=14 ; p<0.05$; Student's $t$ test for paired samples) (Fig. $7 A, C$ ). This was significantly greater than the effects of $30 \mu \mathrm{M}$ DA at room temperature $(\mathrm{df}=$ $13 ; t=3.7 ; p<0.05)$.

We found that the mean $R_{\mathrm{N}}$ of all cells recorded at $\sim 31^{\circ} \mathrm{C}$ was $81 \pm 10 \mathrm{M} \Omega(n=20)$, which was significantly lower than the $R_{\mathrm{N}}$ of cells recorded at room temperature $(\mathrm{df}=94 ; t=4.2 ; p<0.05)$. $R_{\mathrm{N}}$ was measured before, during, and after the application of 30 $\mu \mathrm{M}$ DA $(n=8)$ and showed a significant decrease of $16 \pm 3 \%$ ( $\mathrm{df}=7 ; t=3.5 ; p<0.05)$. In these and all other experiments, measurements of $R_{\mathrm{N}}$ were made while the membrane potential was maintained at baseline levels.

In five of nine of these experiments, as well as in a subset of the previous experiments, a transient increase in the number of spikes, above baseline levels, was observed after the washout of 
A

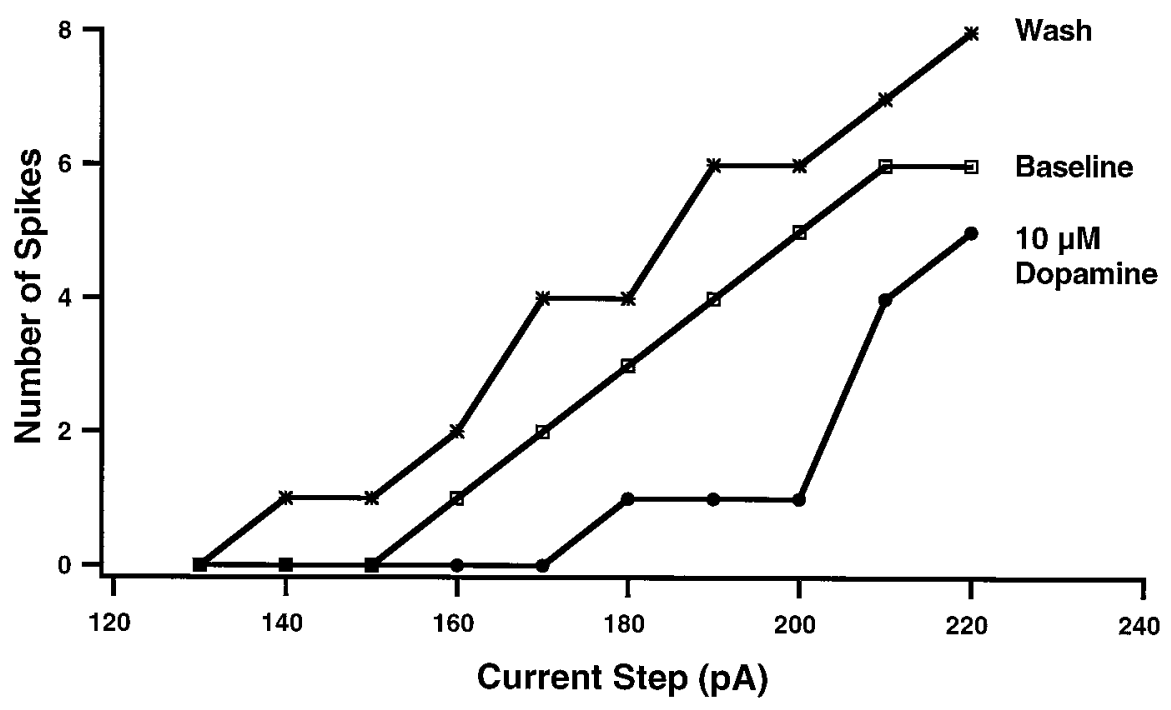

Figure 4. Dopaminergic depression of the number of evoked spikes is not dependent on the level of excitatory input but is correlated with changes in $R_{\mathrm{N}}$. $A$, An example of the current-spike relationship for a cell treated with $30 \mu \mathrm{M} \mathrm{DA}$. This cell, and five of six others, demonstrated an overall depression of excitability, followed by a rebound excitation. $B$, Plot of the relationship between changes in spike number and $R_{\mathrm{N}}$ for all cells from which both measurements were taken.

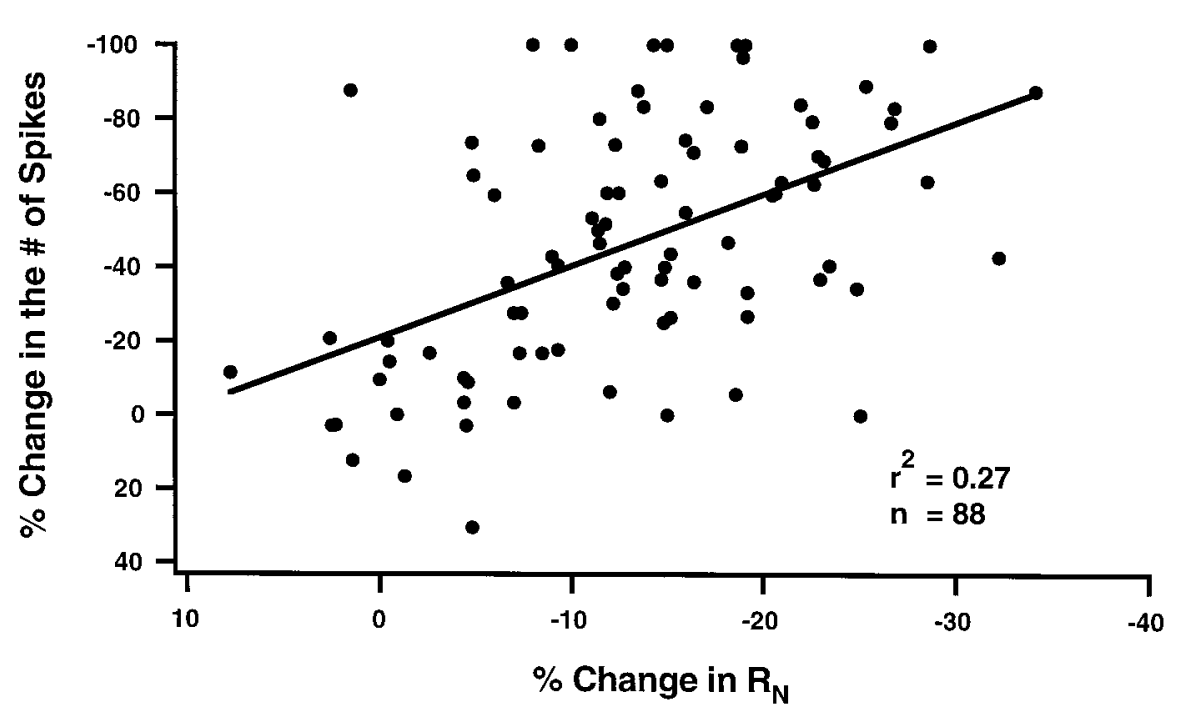

DA (Fig. 7; see also Figs. $2 A, 4 A, 6 A$ ). The magnitude of this rebound effect was $3.2 \pm 0.6$ spikes $(n=5)$, with a corresponding increase in $R_{\mathrm{N}}$ of $9 \pm 3 \%$ from baseline. The time course of this effect was highly variable and not quantified in the present study. Of the cells recorded at room temperature (described above), a rebound excitation in spike number was observed in 16 of the 39 experiments $(41 \%)$ with a mean rebound of $1.1 \pm 0.2$ spikes $(n=16)$.

We also examined the effect of DA on spike threshold and spike latency for cells treated at $\sim 31^{\circ} \mathrm{C}$. Although there was a general trend for the spike threshold to shift to more depolarized levels in DA, the effect was small $(<1 \mathrm{mV})$, was not significant, and did not reverse after the removal of DA. As expected, we observed a reversible increase in spike latency (the time from the beginning of the current pulse to the peak of the first action potential). The increase in spike latency was $79 \pm 13 \%$. In five of nine cells, we also observed shorter spike latency after the washout of DA compared with baseline values, consistent with the rebound effect on spike number, as described above.
Controls for animal age and strain

Rats may show both developmental and strain-related differences in dopaminergic innervation and physiology (Buzsaki et al., 1990; Godefroy et al., 1991). We examined the effect of DA on young adult (10-week-old) Sprague Dawley rats. Figure $8 A$ summarizes the effect of $30 \mu \mathrm{M}$ DA on pyramidal cells from the mPFC of 10 -week-old Sprague Dawley rats. In these cells $(n=4)$ recorded at $\sim 31^{\circ} \mathrm{C}, 30 \mu \mathrm{M}$ DA produced a significant $75 \pm 12 \%$ decrease in the number of spikes ( $\mathrm{df}=9 ; t=5.1 ; p<0.05$ ). Additionally, DA elicited a significant change in $R_{\mathrm{N}}$ of $-16 \pm 3 \%(\mathrm{df}=9 ; t=3.2$; $p<0.05$ ). Similar results were obtained in cells from Long-Evans rats (20- to 30 -d-old) treated with $10 \mu \mathrm{M}$ DA (Fig. $8 B$ ). Of the four cells recorded from Long-Evans $\mathrm{mPFC}$, one was recorded at $\sim 31^{\circ} \mathrm{C}$, and the other three were recorded at room temperature. In these experiments, DA induced a $-71 \pm 11 \%$ change in the number of spikes ( $\mathrm{df}=9 ; t=5.1 ; p<0.05)$ and $\mathrm{a}-13 \pm 3 \%$ change in $R_{\mathrm{N}}(\mathrm{df}=9 ; t=2.5 ; p<0.05)$. Together, these results suggest that DA has a generalized depressive effect on PFC 
A
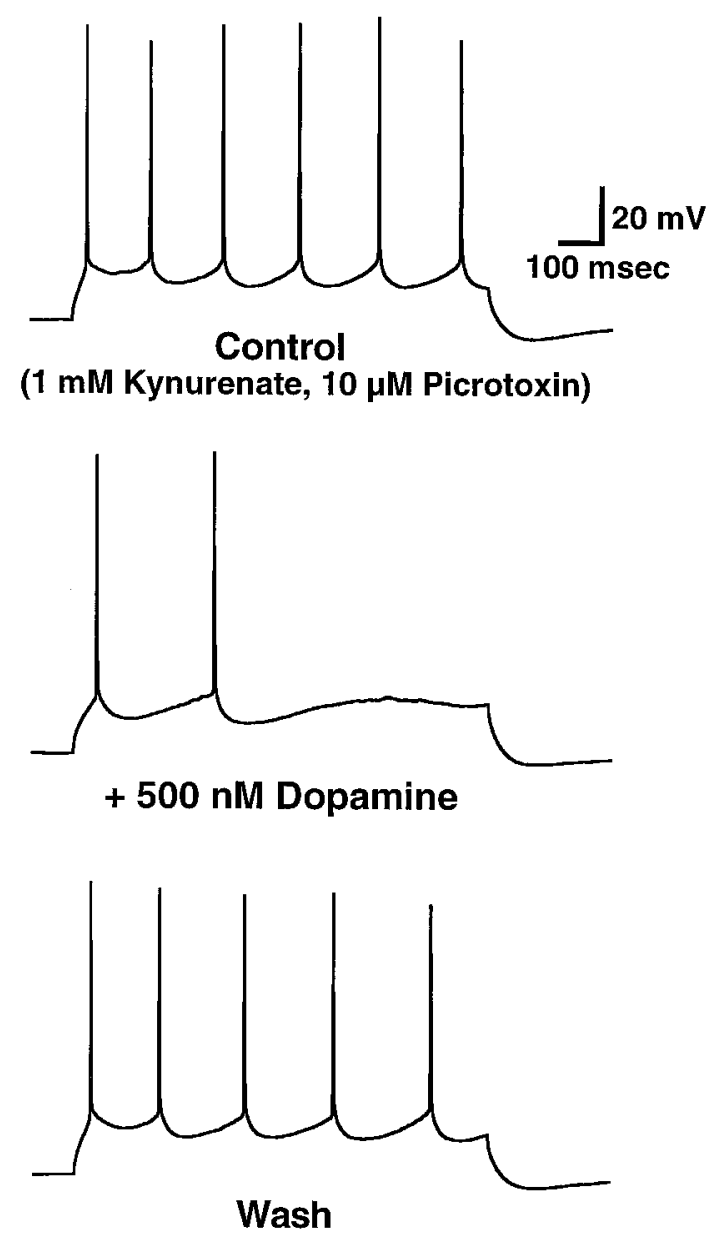

B
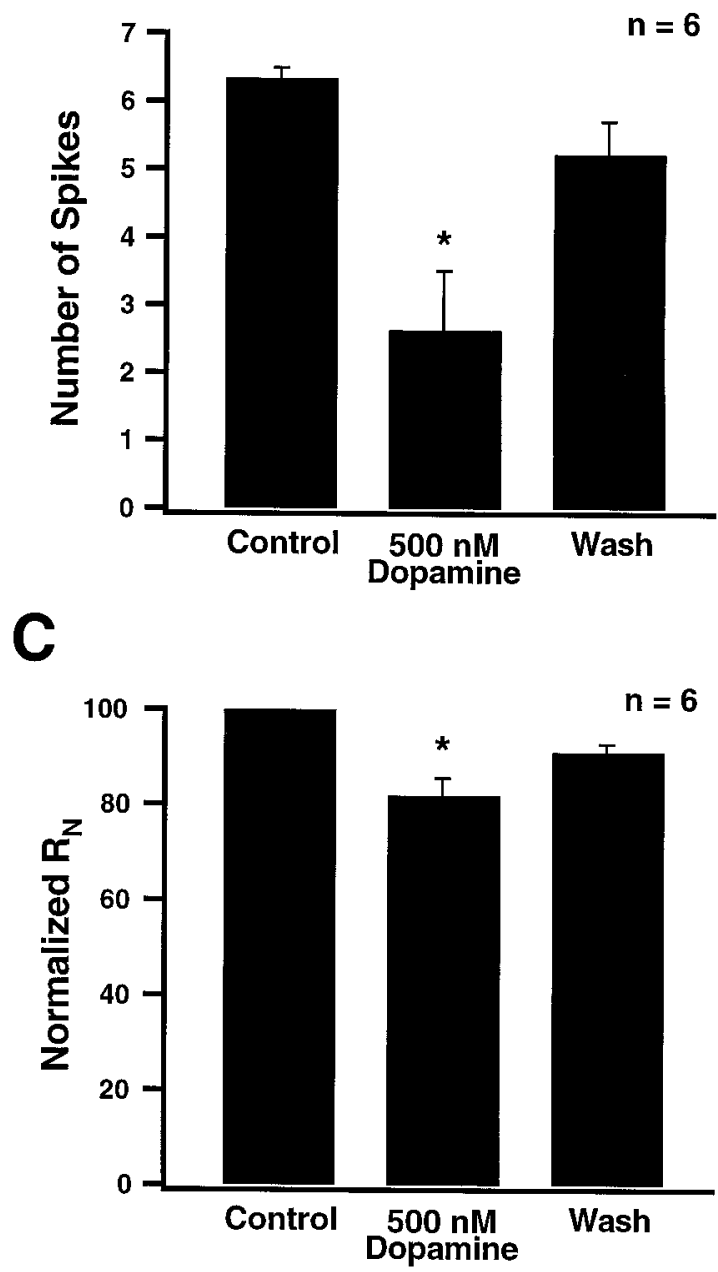

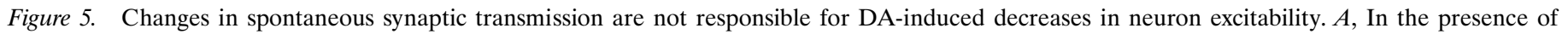

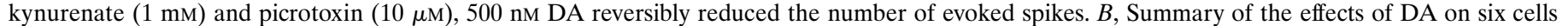
treated with kynurenate and picrotoxin. $C$, Summary of normalized $R_{\mathrm{N}}$ for the same cells as in $B$.

pyramidal cell excitability, which is neither age- nor animalstrain-specific.

\section{Pharmacology of dopaminergic depression of excitability}

To determine which DA receptor subtype might mediate the observed changes in spike number and $R_{\mathrm{N}}$, the effects of DA were challenged by antagonists to either the D1 or D2 family of DA receptors (Fig. $9 A$ ). In the presence of the D1 receptor antagonist SCH $23390(1 \mu \mathrm{M}), 500 \mathrm{~nm}$ DA $(n=7)$ significantly decreased the number of spikes compared with control cells (mean change, $-47 \pm 12 \% ; \mathrm{df}=12 ; t=2.6 ; p<0.05)$. The change in spikes observed in SCH 23390 was not significantly different from changes observed when $500 \mathrm{~nm}$ DA was applied alone $(\mathrm{df}=11$; $t=0.5 ; p>0.05)$. Conversely, when $1 \mu \mathrm{M}$ DA was applied 5 min after the bath application of the D2 receptor antagonist sulpiride ( 1 or $10 \mu \mathrm{M})$, the change in the number of spikes was only $-17 \pm$ $11 \%(n=7)$. This change was not significantly different from control cells treated with nomifensine and ascorbate alone $(\mathrm{df}=$ $12 ; t=0.5 ; p>0.05)$ but was significantly different from cells treated with $1 \mu \mathrm{M} \mathrm{DA}(\mathrm{df}=22 ; t=3.9 ; p<0.05)$. Additional within-cell experiments $(n=3)$ were performed with sulpiride under heated $\left(\sim 31^{\circ} \mathrm{C}\right)$ conditions. Much like the experiments described above, DA $(10 \mu \mathrm{M})$ was added to a bathing solution already containing sulpiride $(10 \mu \mathrm{M})$. After $5 \mathrm{~min}$ of recording, sulpiride was removed from the bath, leaving DA alone (Fig. 10). Figure $10 A$ shows the time course of action potential number for one of these cells. As expected, DA had no effect on spike number while sulpiride was present. However, once sulpiride was removed from the bathing solution, the number of evoked spikes decreased $81 \pm 5 \%(\mathrm{df}=8 ; t=6.6 ; p<0.05)($ Fig. $10 B)$. The application of $10 \mu \mathrm{M} \mathrm{DA}$ in the presence of sulpiride produced only a $-8 \pm 8 \%$ change in $R_{\mathrm{N}}$. Once it was removed, however, there was a significant decrease in $R_{\mathrm{N}}$ of $19 \pm 4 \%(\mathrm{df}=8 ; t=3.4$; $p<0.05$ ) (Fig. 10C). These data suggest that DA modulates pyramidal cell excitability via activation of D2 type receptors.

To further characterize the receptor subtype involved, specific agonists to D1 or D2 receptors were applied (Fig. 9A). Bath application of the D1 receptor agonist SKF $38393(5 \mu \mathrm{M})$ resulted in an $18 \pm 6 \%$ decrease in the number of spikes $(n=7)$, although this was not significantly different from controls ( $\mathrm{df}=12 ; t=0.8$; $p>0.05)$. Similarly, the bath application of another more selective D1 agonist, SKF 81297, did not produce a significant change 
A
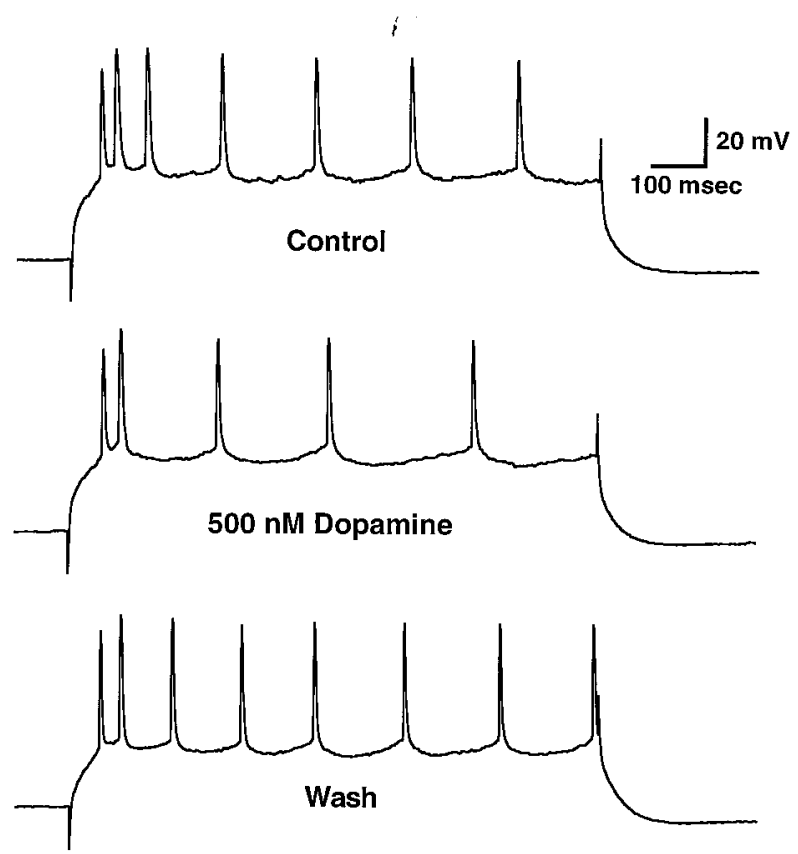

B

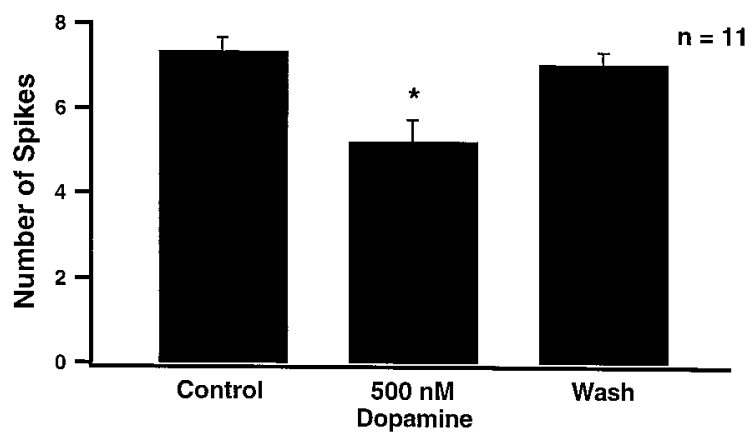

Figure 6. DA-induced decreases in neuron excitability are not caused by whole-cell washout. $A$, Perforated-patch recording of evoked spikes. In this example, $500 \mathrm{~nm}$ DA reversibly depressed the number of spikes. $B$, Summary of the number of spikes before, during, and after the application of $500 \mathrm{~nm}$ DA for 11 cells recorded with the perforated-patch technique.

in spike number (mean change, $-10 \pm 3 \% ; n=4$ ). Although these D1 agonists appear ineffective in inhibiting pyramidal cell firing, exposure to the D2 receptor agonist quinpirole $(1 \mu \mathrm{M})$ resulted in a significant $47 \pm 14 \%$ decrease in the number of evoked spikes $(n=5$; df $=10 ; t=2.6 ; p<0.05)$.

In contrast to their effects on spike number, neither the D1 antagonist SCH 23390 nor the D2 antagonist sulpiride blocked the effects of DA on $R_{\mathrm{N}}$ (Fig. $9 B$ ). However, only the D2 agonist quinpirole was consistently effective in producing a significant decrease in $R_{\mathrm{N}}$ compared with controls (mean change, $-15 \pm 1 \%$; df $=9 ; t=3.3 ; p<0.05$ ). Neither SKF 38393 (mean change, $-14 \pm 6 \% ; n=7$ ) nor SKF 81297 (mean change, $-5 \pm 2 \% ; n=$ 4) produced significant changes in $R_{\mathrm{N}}$. Together, these experiments indicate that $\mathrm{D} 2$ receptor activation may preferentially depress $R_{\mathrm{N}}$, although a contribution of D1 receptors is also suggested.

\section{DISCUSSION}

\section{Cellular effects of DA}

In this study, we found that DA depressed the excitability of layer $\mathrm{V}$ pyramidal neurons, as indicated by decreases in both the number of evoked spikes and $R_{\mathrm{N}}$. The effect of DA on action potential number was comparable over a wide range of DA concentrations (50 nм to $30 \mu \mathrm{M})$; there was no inverted U-shaped relationship between DA and pyramidal neuron firing. Interestingly, however, we did observe such a relationship between the concentration of DA and decreases in $R_{\mathrm{N}}$. There was a window of DA concentrations ( $50 \mathrm{nM}$ to $1 \mu \mathrm{M}$ ) that effectively depressed $R_{\mathrm{N}}$.

Although our results are generally consistent with results from in vivo experiments in rodents (Ferron et al., 1984; Mantz et al., 1988; Yang and Mogenson, 1990; Pirot et al., 1992) and the in vitro study of Geijo-Barrientos and Pastore (1995), three other studies on layer $\mathrm{V}$ pyramidal neurons have reported DA-induced increases in excitability (Table 1). Yang and Seamans (1996) found that D1 receptor activation was responsible for increasing pyramidal neuron excitability via the facilitation and depression of $\mathrm{Na}^{+}$and $\mathrm{K}^{+}$currents, respectively. Shi et al. (1997) observed a significant DA-induced depolarization with a concomitant increase in firing. In a study of the actions of DA on synaptic transmission, no significant effect of DA on excitability was reported (Law-Tho et al., 1994). The only consistent observation among these studies is that DA depolarizes layer $\mathrm{V}$ pyramidal neurons.

What might account for the wide variability in the results of the different in vitro experiments described above? An examination of the studies presented in Table 1 suggests no significant differences in the age of the animals, no apparent correlation with the concentration of DA, and no obvious differences in the in vitro techniques used, except, perhaps, our use of whole-cell patch recording.

Control experiments with perforated-patch electrodes rule out the possibility that intracellular dialysis by whole-cell pipettes affected our results. In these experiments, DA still induced a reduction in evoked action potentials, albeit smaller than in whole-cell experiments. During many of the perforated-patch experiments, there was a progressive decrease in $R_{\mathrm{S}}$ during the course of the experiment, presumably caused by an increasing concentration of nystatin at the pipette tip. A slow decrease in $R_{\mathrm{S}}$

Table 1. Investigations of dopamine effects on PFC pyramidal cells

\begin{tabular}{|c|c|c|c|c|c|c|}
\hline Study & Animal size & $\mathrm{DA}(\mu \mathrm{M})$ & $\Delta$ Spikes & $\Delta$ Latency & $\Delta R_{\mathrm{N}}$ & $\Delta V_{\mathrm{m}}$ \\
\hline Penit-Soria et al. (1987) & $18-23 \mathrm{~d}$ & 400 & $\uparrow$ & $\downarrow$ & $\uparrow$ & $\uparrow$ \\
\hline Law-Tho et al. (1994) & $20-30 \mathrm{~d}$ & $50-100$ & $\mathrm{NC}$ & $\mathrm{NC}$ & $\mathrm{NC}$ & $\uparrow$ \\
\hline Geijo-Barrientos and Pastore (1995) & $150-200 \mathrm{gm}$ & $0.1-10$ & $\downarrow$ & $\uparrow$ & $\mathrm{NC}$ & $\uparrow$ \\
\hline Yang and Seamans (1996) & $80-100 \mathrm{gm}$ & $2-50$ & $\uparrow$ & $\downarrow$ & $\downarrow$ & $\uparrow / \downarrow$ \\
\hline Shi et al. (1997) & $40-120 \mathrm{gm}$ & $1-500$ & $\uparrow *$ & NA & $\mathrm{NC}$ & $\uparrow$ \\
\hline Gulledge and Jaffe (present study) & $17-30 \mathrm{~d} / 10$ week & $0.01-30$ & $\downarrow$ & $\uparrow$ & $\downarrow$ & $\uparrow$ \\
\hline
\end{tabular}

$\uparrow$, Increase with DA; $\downarrow$, decrease with DA; NC, no change with DA; NA, data not available.

* Spikes in DA were evoked from depolarized membrane potentials. 

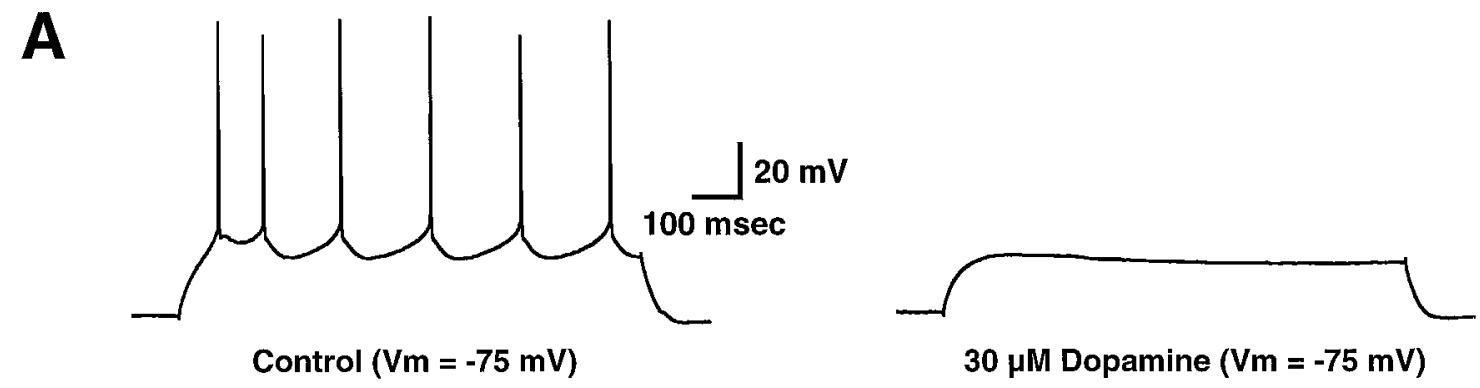

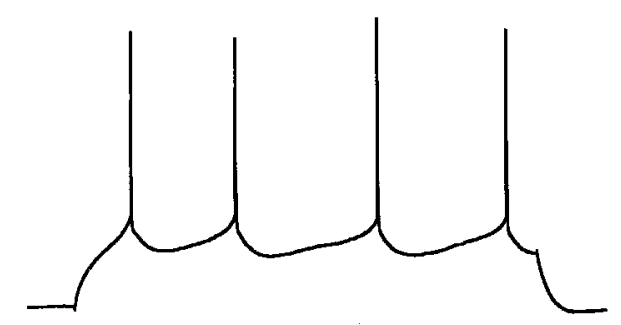

$30 \mu \mathrm{M}$ Dopamine $(\mathrm{Vm}=-73 \mathrm{mV})$

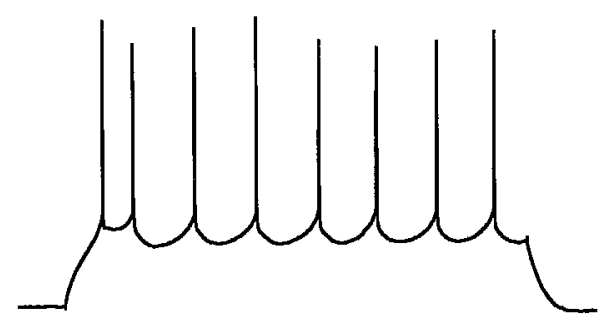

Wash $(\mathrm{Vm}=-75 \mathrm{mV})$

B

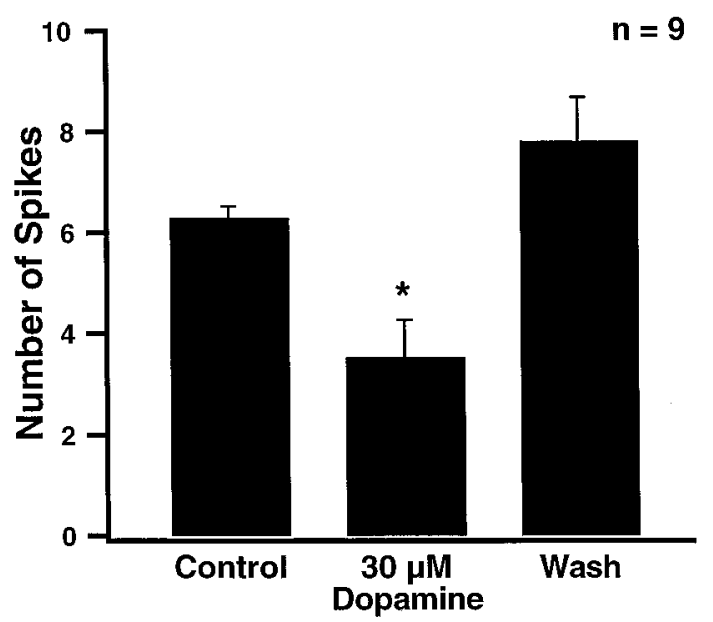

No bias current
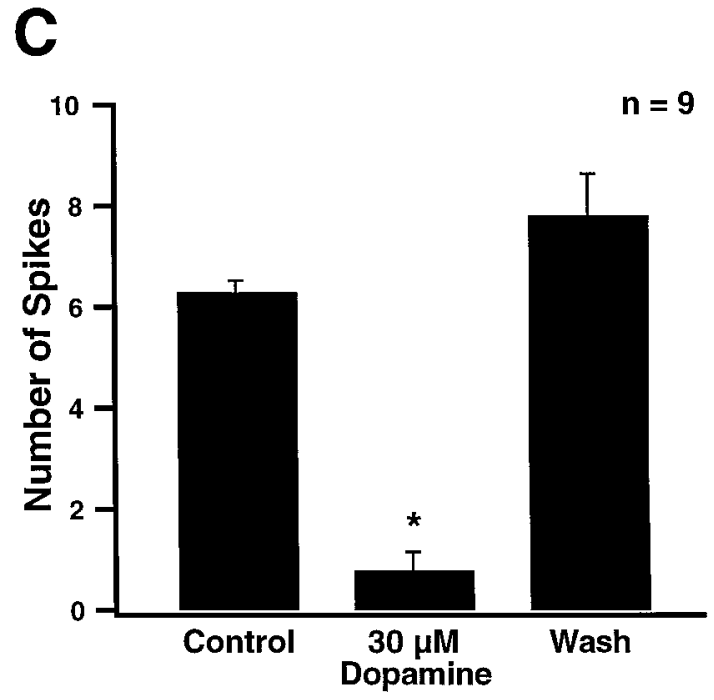

Vm held at baseline values

Figure 7. The effect of DA on neuron excitability at $\sim 31^{\circ} \mathrm{C}$. $A$, Application of $30 \mu \mathrm{M}$ DA depolarized the resting potential from $-75 \mathrm{mV}$ to $-73 \mathrm{mV}$. The number of action potentials generated by $300 \mathrm{pA}$ decreased from six to four spikes (left traces). When bias current ( $\sim 25 \mathrm{pA})$ was used to hold the membrane potential at $-75 \mathrm{mV}, 300 \mathrm{pA}$ was unable to evoke spikes (top right). After 5 min washout, membrane potential returned to $-75 \mathrm{mV}$ and 300 pA injection evoked eight spikes (bottom right). $B$, Summary of the effects of DA when the membrane potential was allowed to depolarize (no bias current was applied). $C$, Summary of the effects of DA when bias current was used to hold the $V_{\mathrm{m}}$ to baseline values.

would, by itself, tend to increase the membrane response to current injections. Alternatively, because DA receptor coupling to second-messenger systems is dependent on intracellular GTP (Jackson and Westlind-Danielsson, 1994), the increased effect of DA during whole-cell experiments may be caused by elevated levels of GTP in the pipette solution.

Might DA modulate neuron excitability through an effect on synaptic transmission? DA has been reported to excite nonpyramidal and presumably GABAergic cells in the rat mPFC (PenitSoria et al., 1987; Yang et al., 1997; Zheng et al., 1997). An increase in GABA transmission would be expected to produce decreases in both $R_{\mathrm{N}}$ and spiking activity in pyramidal neurons.
All of the groups listed in Table 1, except Geijo-Barrientos and Pastore (1995), included the GABA $_{\mathrm{A}}$ receptor blocker bicuculline in their experiments. Results from our experiments in which both ionotropic glutamate and $\mathrm{GABA}_{\mathrm{A}}$ receptors were blocked suggest that our results are not attributable to changes in fast synaptic transmission. The influence of $\mathrm{GABA}_{\mathrm{B}}$ receptors or the actions of other neuromodulators on pyramidal cell excitability, however, cannot be ruled out.

At least four of the other five studies listed in Table 1 were performed at temperatures above $30^{\circ} \mathrm{C}$ (Shi et al., 1997 did not specify temperature), and it is not implausible that DA-induced excitability is temperature dependent. If this were the case, exci- 


\section{Week-Old Animals}

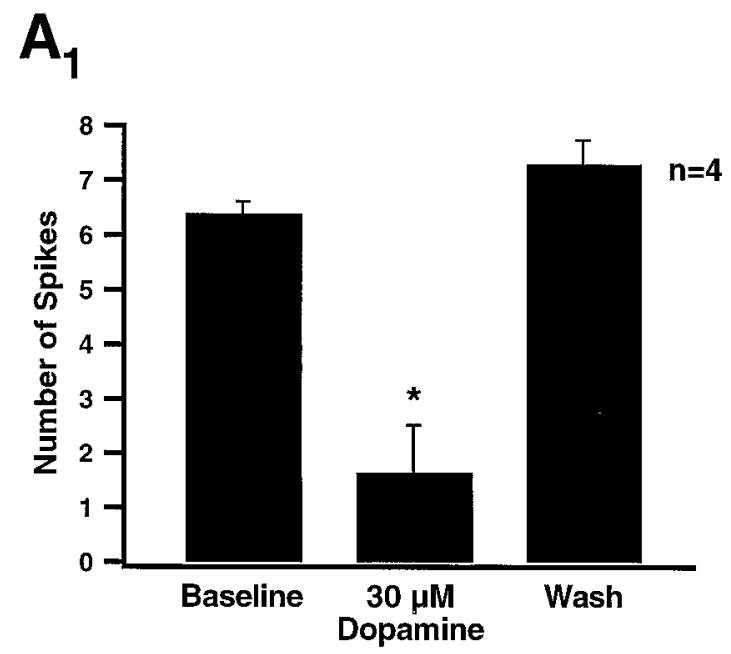

$A_{2}$

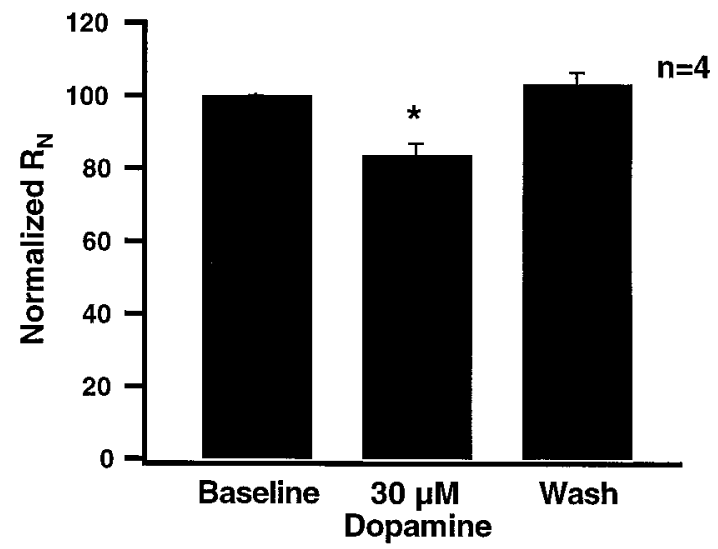

Long Evans Rats

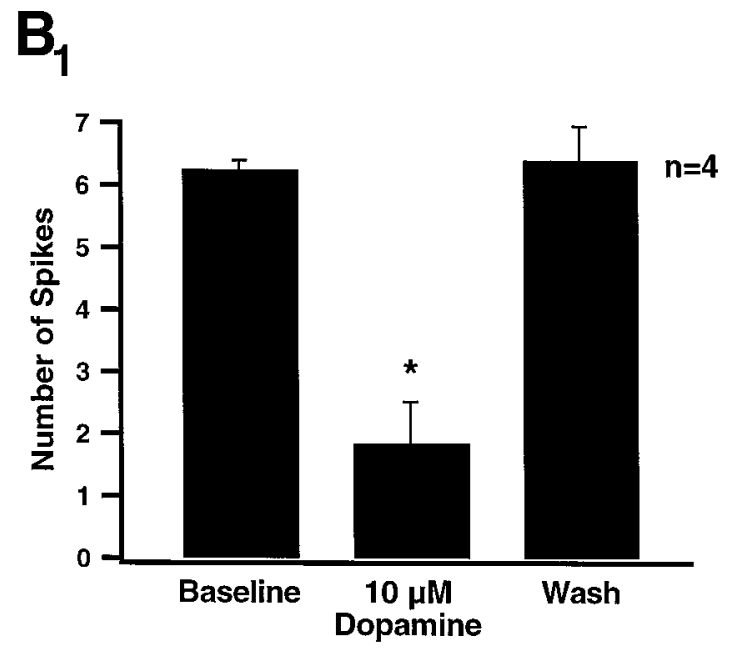

$B_{2}$

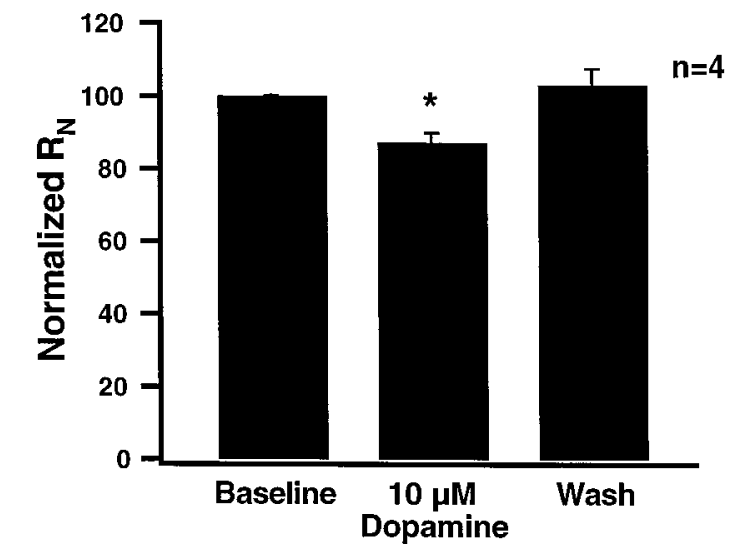

Figure 8. Effects of DA are not age- or animal-strain-specific. A, Summary of data collected from PFC slices obtained from 10-week-old Sprague Dawley rats. The application of $30 \mu \mathrm{M}$ DA reversibly decreased both spike number and $R_{\mathrm{N}}(n=4) . B$, Summary of data obtained from four cells recorded from slices of PFC from Long-Evans rats. In these experiments, $10 \mu \mathrm{M}$ DA induced decreases in spike number and $R_{\mathrm{N}}$ similar to those seen in Sprague Dawley rats.

tatory effects of DA might not be observed in experiments conducted at room temperature. However, in the present study, we have found that at $\sim 31^{\circ} \mathrm{C}$, DA exerted a more potent inhibition of cell firing.

DA receptors can exhibit rapid desensitization after agonist binding (Lohse, 1993; Freedman and Lefkowitz, 1996), and desensitization of specific receptor types may occur during prolonged bath application of DA (but see Law-Tho et al., 1994; Geijo-Barrientos and Pastore, 1995) rather than during relatively brief exposure to DA (Yang and Seamans, 1996). If receptor desensitization were responsible for the decreases in excitability reported here, we would have expected to see an initial increase in excitability during DA application. As exemplified in Figure $2 B$, no transient increases in excitability were observed during the initial periods of DA exposure. Additionally, inactivation during prolonged DA exposure might reveal an increase in excitability. This was not supported by the experiments in which the duration of DA exposure was increased from 5 to $20 \mathrm{~min}$. Finally, there may be more complex time-dependent effects of DA. For example, tonic activation of DA receptors may inhibit the activity of PFC neurons, whereas more acute or phasic exposure to DA may enhance excitability. Further experiments will be needed to test this hypothesis.

It may be possible that developmental differences account for the action of DA on these neurons (Buzsaki et al., 1990; Godefroy et al., 1991). Although all of the age-ranges listed in Table 1 are similar, we attempted to make sure that our results were not dependent on the developmental stage of these animals by repeating experiments using older (10-week-old) rats. We observed no differences in the effects of DA between younger and 10-week- 
A
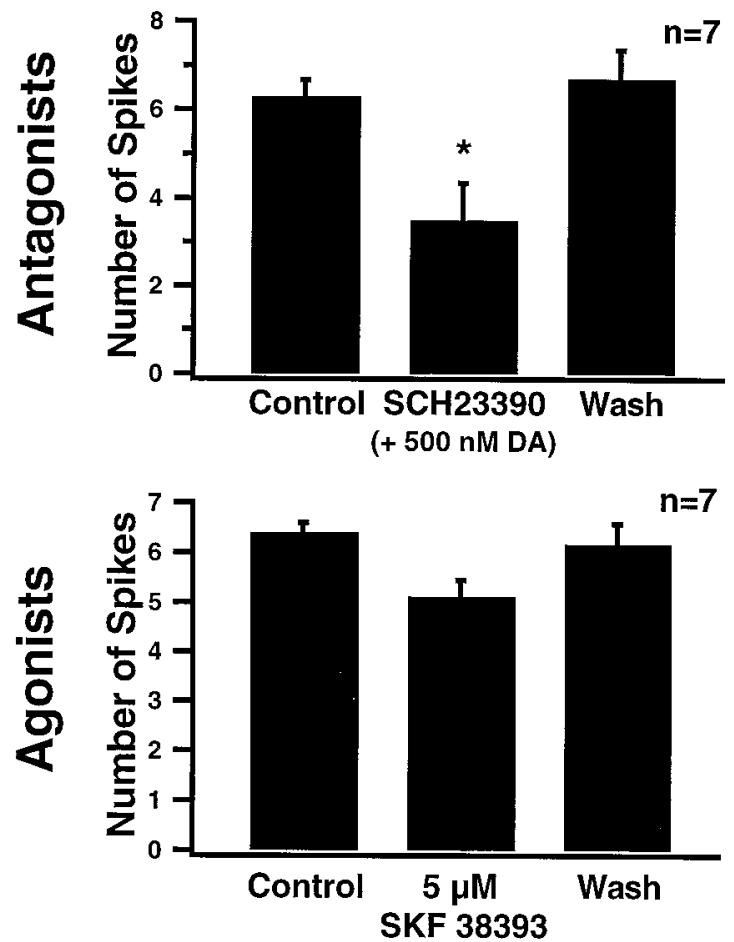

D2
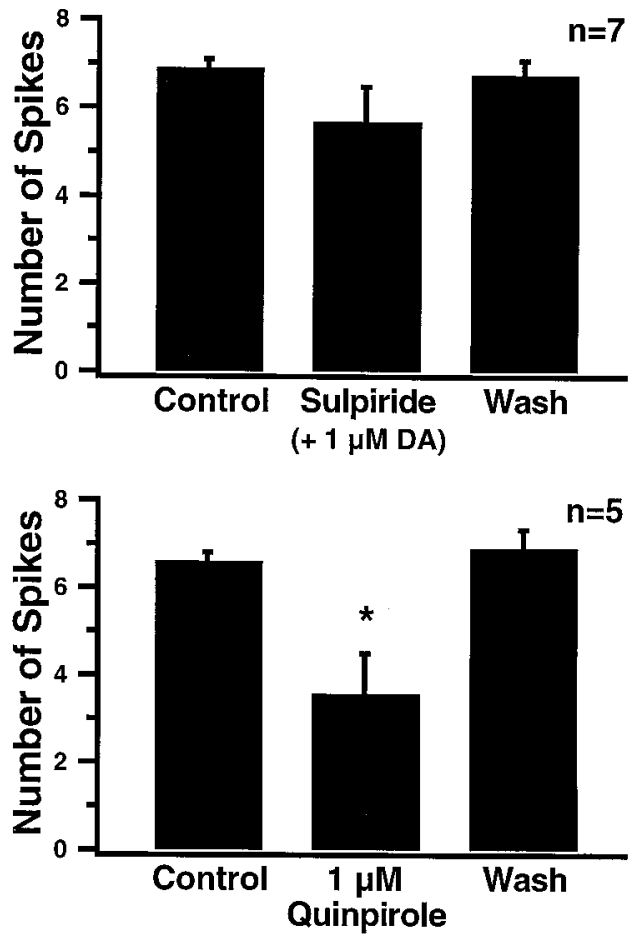

$\mathbf{B}$

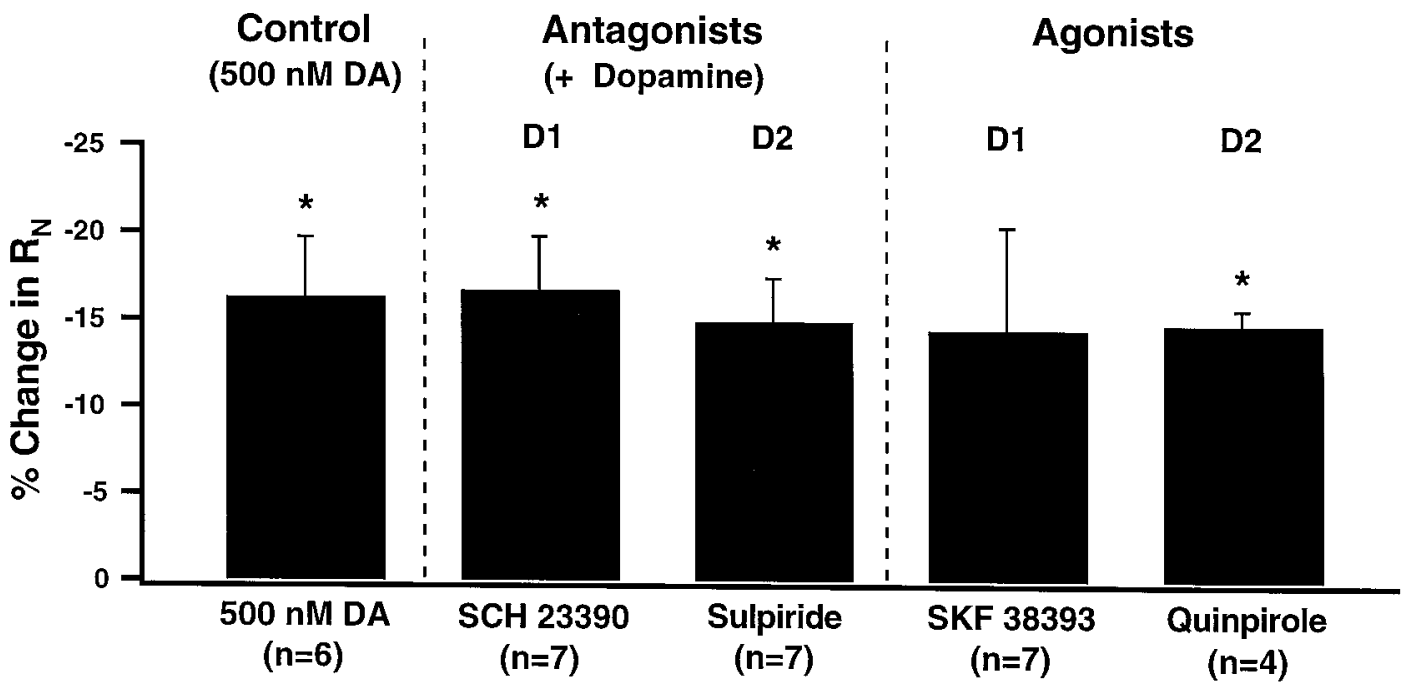

Figure 9. DA may depress layer $\mathrm{V}$ pyramidal neuron excitability via a $\mathrm{D} 2$ receptor subtype. $A$, The number of spikes before, during, and after the bath application of DA in the presence of a D1 or D2 antagonist (top row) or the application of a D1 or D2 agonist (bottom row). The D2 antagonist sulpiride $(1$ or $10 \mu \mathrm{M})$ blocked the effects of $500 \mathrm{nM} \mathrm{DA}$, whereas the D1 antagonist SCH $23390(1 \mu \mathrm{M})$ had no significant effect. In addition, only the D2 agonist quinpirole $(1 \mu \mathrm{M})$ mimicked the effect of DA. $B$, Changes in $R_{\mathrm{N}}$ for the different agonist and antagonist treatments, as well as for 500 nM DA alone.

old animals, suggesting that the effects of DA on these cells are stable throughout young adulthood.

Whereas most of the studies outlined in Table 1 used Sprague Dawley rats, both Geijo-Barrientos and Pastore (1995) and PenitSoria et al. (1987) used slices obtained from Wistar rats, raising the possibility that there may be strain-specific differences in DA physiology in the mPFC. Our results from young Long-Evans rats and the results of Geijo-Barrientos and Pastore (1995) suggest instead that the action of micromolar concentrations of DA on layer $\mathrm{V}$ pyramidal cells of the $\mathrm{mPFC}$ is consistent across a variety of animal strains.

\section{Pharmacology of dopamine response}

In contrast to the numerous behavioral reports demonstrating D1 effects on PFC function in nonhuman primates and rodents (Sawaguchi and Goldman-Rakic, 1991; Seamans et al., 1995; 
A

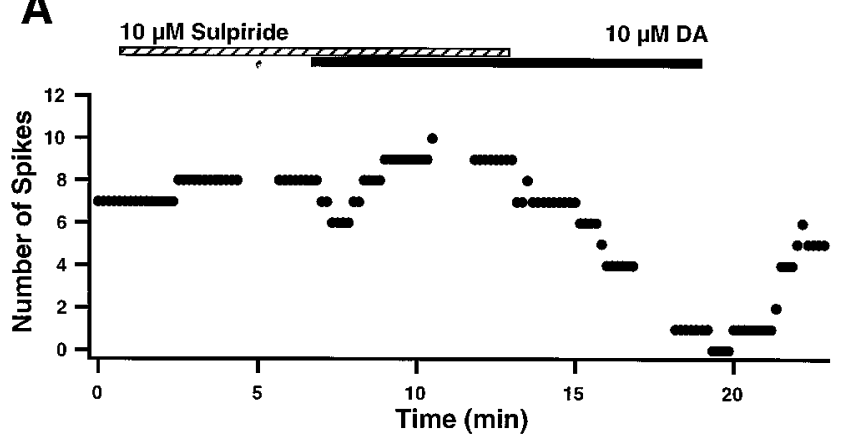

B
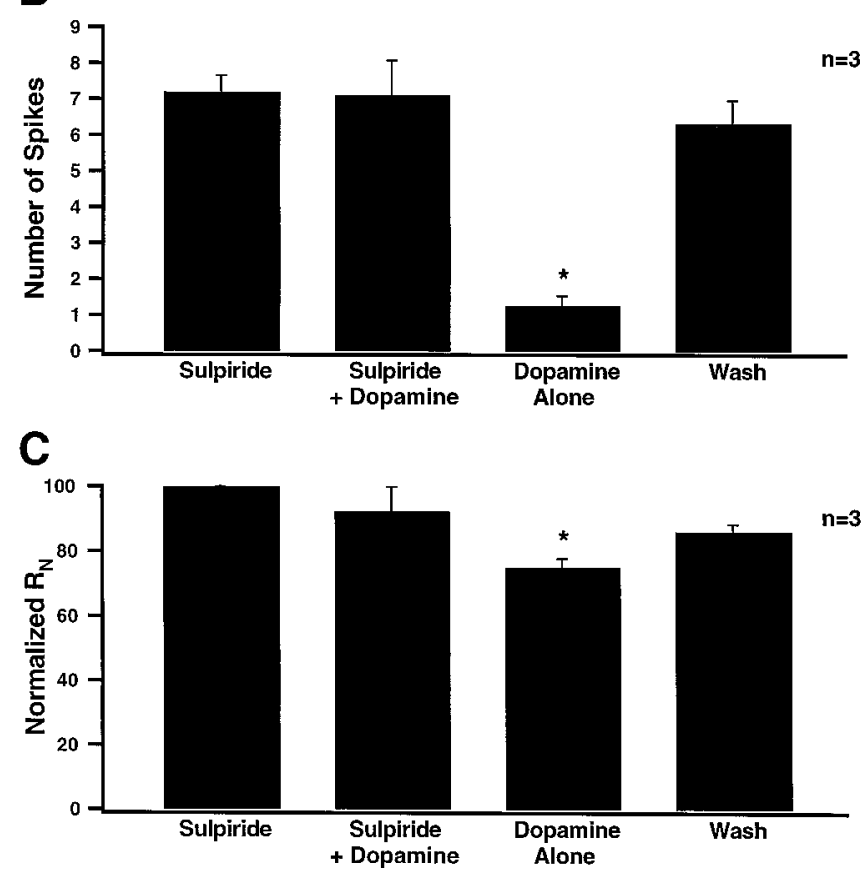

Figure 10. Sulpiride reversibly blocks the effect of DA. A, Example of time course from an experiment in which sulpiride $(10 \mu \mathrm{M})$ was bath applied before the addition of $10 \mu \mathrm{M}$ DA. In the presence of sulpiride, DA did not depress spike number. However, once sulpiride was washed out, a reversible decrease in the number of spikes was observed. $B$, Summary of changes in the number of evoked spikes for within-cell sulpiride experiments $(n=3)$. $C$, Summary of changes in $R_{\mathrm{N}}$.

Williams and Goldman-Rakic, 1995; Yang and Seamans, 1996; Zahrt et al., 1997; Seamans et al., 1998; but see Verma and Moghaddam, 1996), there are a number of in vivo studies suggesting that $\mathrm{D} 2$ receptor activation results in an inhibition of neuronal firing in rat mPFC (Sesack and Bunney, 1989; Parfitt et al., 1990; Yang and Mogenson, 1990). Consistent with these in vivo studies, the dopaminergic depression of cell firing we report here appears to be associated with D2 receptor activation (Fig. 9).

The effect of DA on $R_{\mathrm{N}}$ appeared to be better associated with D2 receptor activation because the $\mathrm{D} 2$ agonist preferentially produced decreases in $R_{\mathrm{N}}$, whereas the D1 agonists did not. However, the experiments with D1 and D2 antagonists suggest that the effects of DA on $R_{\mathrm{N}}$ may result from cross-reactivity between the two receptor subtypes or the activation of other receptor types.

DA modulates the excitability of cells in other brain systems, including CA1 pyramidal cells in the rat hippocampus. As in the mPFC, reports of the effects of DA on CA1 cells have been difficult to reconcile. Several studies have indicated that DA has an inhibitory effect on their excitability (Stanzione et al., 1984; Pockett, 1985; Cantrell et al., 1997), whereas others have suggested an excitatory role (Malenka and Nicoll, 1986; Pedarzani and Storm, 1995). Although inhibitory influences of DA have been shown to be mediated via DA receptor activation (Stanzione et al., 1984; Cantrell et al., 1997), the excitatory effects of DA were not blocked by DA receptor antagonists (Malenka and Nicoll, 1986; Pedarzani and Storm, 1995). An interesting finding by Malenka and Nicoll (1986) was that DA $(10-100 \mu \mathrm{M})$ increases cell excitability via the activation of $\beta$-adrenergic receptors. Although Pedarzani and Storm (1995) dispute this finding, it may be that DA can activate adrenergic receptors in mPFC. Under certain conditions, these or other receptors may be amenable to DA activation, and such cross-reactivity may explain the highly variable results observed in both the hippocampus and mPFC.

\section{Models of dopaminergic modulation}

A functional result of dopaminergic inhibition of excitability is to increase the signal-to-noise level of pyramidal cell output. Only those cells receiving strong synaptic input, presumably those with significant information content, will fire (Spitzer and Neumann, 1996). In addition to damping the effect of excitatory synaptic input, DA may also play a roll in synaptic plasticity; DA facilitates the induction of long-term depression of synapses onto layer $\mathrm{V}$ mPFC neurons (Law-Tho et al., 1995; Otani et al., 1998).

Yang and Seamans (1996) have proposed an interesting model for dopaminergic modulation of signal integration in layer $\mathrm{V}$ pyramidal cells in the mPFC. They suggest that D1 receptor activation may transiently change the integrative weight of apical (presumably cortico-cortical) verses basal (presumably subcortical) synaptic input to layer $\mathrm{V}$ pyramidal cells and therefore modify PFC output. An integrative modulation such as this, together with signal filtering proposed here via a D2-associated depression of excitability, may establish a necessary state of the PFC network for proper working memory function. A more detailed understanding of the effects of DA on these and other cell types of the mPFC will provide a basis for a more complete understanding of information processing in this area of the brain.

\section{REFERENCES}

Bernardi G, Cherubini E, Marciani MG, Mercuri N, Stanzione P (1982) Responses of intracellularly recorded cortical neurons to the iontophoretic application of dopamine. Brain Res 245:267-274.

Bjorklund A, Divac I, Lindvall O (1978) Regional distribution of catecholamines in monkey cerebral cortex, evidence for a dopaminergic innervation of the primate prefrontal cortex. Neurosci Lett 7:115-119.

Brown RM, Crane AM, Goldman PS (1979) Regional distribution of monoamines in the cerebral cortex and subcortical structures of the rhesus monkey: concentrations and in vivo synthesis rates. Brain Res 168:133-150.

Brozoski TJ, Brown RM, Rosvold HE, Goldman PS (1979) Cognitive deficit caused by regional depletion of dopamine in prefrontal cortex of rhesus monkey. Science 205:929-932.

Bubser M, Schmidt WJ (1990) 6-OHDA lesions of the rat prefrontal cortex increases locomotor activity, impairs acquisition of delayed alternation tasks, but does not affect uninterrupted tasks in the radial maze. Behav Brain Res 37:157-168.

Buzsaki G, Laszlovszky I, Lajtha A, Vadasz C (1990) Spike-and-wave neocortical patterns in rats: genetic and aminergic control. Neuroscience 38:323-333.

Cantrell AR, Smith RD, Goldin AL, Scheuer T, Catterall WA (1997) Dopaminergic modulation of sodium current in hippocampal neurons via cAMP-dependent phosphorylation of specific sites in the sodium channel $\alpha$ subunit. J Neurosci 17:7330-7338.

Carr DB, Sesack SR (1996) Hippocampal afferents to the rat prefrontal cortex: synaptic targets and relation to dopamine terminals. J Comp Neurol 369:1-15. 
Chitwood R, Claiborne BJ, Jaffe DB (1997) Modelling the passive properties of nonpyramidal neurons in hippocampal area CA3. In: Computational neuroscience: trends in research (Bower JM, ed), pp 59-64. New York: Plenum.

Condé F, Audinat E, Maire-Lepoivre E, Crépel F (1990) Afferent connections of the medial frontal cortex of the rat. A study using retrograde transport of fluorescent dyes. I. Thalamic afferents. Brain Res Bull 24:341-354.

Condé F, Maire-Lepoivre E, Audinat E, Crépel F (1995) Afferent connections of the medial frontal cortex of the rat. II. Cortical and subcortical afferents. J Comp Neurol 352:567-593.

Descarries L, Lemay B, Doucet G, Berger B (1987) Regional and laminar density of the dopamine innervation in adult rat cerebral cortex. Neuroscience 21:807-824.

Emson PC, Koob GF (1978) The origin and distribution of dopaminecontaining afferents to the rat frontal cortex. Brain Res 142:249-267.

Ferron A, Thierry AM, Douarin CL, Glowinski J (1984) Inhibitory influence of the mesocortical dopaminergic system on the spontaneous activity or excitatory response induced from the thalamic mediodorsal nucleus in the rat medial prefrontal cortex. Brain Res 302:257-265.

Freedman NJ, Lefkowitz RJ (1996) Desensitization of G proteincoupled receptors. Recent Prog Horm Res 51:319-353.

Funahashi S, Bruce CJ, Goldman-Rakic PS (1991) Neuronal activity related to saccadic eye movements in the monkey's dorsolateral prefrontal cortex. J Neurophysiol 65:1464-1483.

Geijo-Barrientos E, Pastore C (1995) The effects of dopamine on the subthreshold electrophysiological responses of rat prefrontal cortex neurons in vitro. Eur J Neurosci 7:358-366.

Godefroy F, Bassant MH, Lamour Y, Weil-Fugazza J (1991) Effect of aging on dopamine metabolism in the rat cerebral cortex: a regional analysis. J Neural Transm Gen Sect 83:13-24.

Gulledge AT, Jaffe DB (1997) Dopamine decreases the excitability of layer $\mathrm{V}$ pyramidal cells in the rat prefrontal cortex. Soc Neurosci Abstr 23:655.

Haj-Dahmane S, Andrade R (1997) Calcium-activated cation nonselective current contributes to the fast afterdepolarization in rat prefrontal cortex neurons. J Neurophysiol 78:1983-1989.

Houser CR, Hendry SHC, Jones EG, Vaughn VE (1983) Morphological diversity of immuno-cytochemically identified GABA neurons in monkey sensory-motor cortex. J Neurocytol 12:617-638.

Jackson DM, Westlind-Danielsson A (1994) Dopamine receptors: molecular biology, biochemistry, and behavioural aspects. Pharmacol Ther 64:291-369.

Kawaguchi Y (1993) Groupings of nonpyramidal and pyramidal cells with specific physiological and morphological characteristics in rat frontal cortex. J Neurophysiol 69:416-431.

Kawaguchi Y, Kubota Y (1993) Correlation of physiological subgroupings of nonpyramidal cells with parvalbumin- and calbindinD28kimmunoreactiveneurons in layer $\mathrm{V}$ of rat frontal cortex. J Neurophysiol 70:387-396.

Law-Tho D, Hirsch JC, Crépel F (1994) Dopamine modulation of synaptic transmission in rat prefrontal cortex: an in vitro electrophysiological study. Neurosci Res 21:151-160.

Law-Tho D, Desce JM, Crépel F (1995) Dopamine favours the emergence of long-term depression versus long-term potentiation in slices of rat prefrontal cortex. Neurosci Lett 188:125-128.

Lohse MJ (1993) Molecular mechanisms of membrane receptor desensitization. Biochim Biophys Acta 1179:171-188.

Malenka RC, Nicoll RA (1986) Dopamine decreases the calciumactivated afterhyperpolarization in hippocampal CA1 pyramidal cells. Brain Res 379:210-215.

Mantz J, Milla C, Glowinski J, Thierry AM (1988) Differential effects of ascending neurons containing dopamine and noradrenaline in the control of spontaneous activity and of evoked responses in the rat prefrontal cortex. Neuroscience 27:517-526.

Murphy BL, Arnsten AF, Goldman-Rakic PS, Roth RH (1996) Increased dopamine turnover in the prefrontal cortex impairs working memory performance in rats and monkeys. Proc Natl Acad Sci USA 93:1325-1329.

Otani S, Blond O, Desce JM, Crépel F (1998) Dopamine facilitates long-term depression of glutamatergic transmission in rat prefrontal cortex. Neuroscience 85:669-676.

Parfitt KD, Gratton A, Bickford-Wimer PC (1990) Electrophysiological effects of selective D1 and D2 dopamine agonists in the medial prefrontal cortex of young and aged rats. J Pharmacol Exp Ther 254:539-545.
Pedarzani P, Storm JF (1995) Dopamine modulates the slow $\mathrm{CA}^{2+}$ -activated $\mathrm{K}^{+}$current $I_{\mathrm{AHP}}$ via cyclic AMP-dependent protein kinase in hippocampal neurons. J Neurophysiol 74:2749-2753.

Penit-Soria J, Audinat E, Crépel F (1987) Excitation of rat prefrontal cortical neurons by dopamine: an in vitro electrophysiological study. Brain Res 425:263-274.

Pirot S, Godbout R, Mantz J, Tassin JP, Glowinski J, Thierry AM (1992) Inhibitory effects of ventral tegmental area stimulation on the activity of prefrontal cortical neurons: evidence for the involvement of both dopaminergic and GABAergic components. Neuroscience 49:857-865.

Pockett S (1985) Dopamine changes the shape of action potentials in hippocampal pyramidal cells. Brain Res 342:386-390.

Sah P, Hestrin S, Nicoll RA (1989) Tonic activation of NMDA receptors by ambient glutamate enhances excitability of neurons. Science 246: 815-818.

Sawaguchi T, Goldman-Rakic PS (1991) D1 dopamine receptors in prefrontal cortex: involvement in working memory. Science 251:947-950.

Sawaguchi T, Goldman-Rakic PS (1994) The role of D1-dopamine receptor in working memory: local injections of dopamine antagonists into the prefrontal cortex of rhesus monkeys performing an oculomotor delayed-response task. J Neurophysiol 71:515-528.

Seamans JK, Floresco SB, Phillips AG (1998) D1 receptor modulation of hippocampal-prefrontal cortical circuits integrating spatial memory with executive function in the rat. J Neurosci 18:1613-1621.

Seamans JK, Gorelova N, Yang CR (1995) Selective impairment on a delayed radial arm task following local administration of a selective D1, but not a D2, antagonist into the prefrontal cortex. Soc Neurosci Abstr 21:1942.

Sesack SR, Bunney BS (1989) Pharmacological characterization of the receptor mediating electrophysiological responses to dopamine in the rat medial prefrontal cortex: a microiontophoretic study. J Pharmacol Exp Ther 248:1323-1333.

Shi W, Zheng P, Liang X, Bunney BS (1997) Characterization of dopamine-induced depolarization of prefrontal cortical neurons. Synapse 26:415-422.

Simon H, Scatton B, LeMoal M (1980) Dopaminergic A10 neurons are involved in cognitive functions. Nature 286:150-151.

Softky WR, Koch C (1993) The highly irregular firing of cortical cells is inconsistent with temporal integration of random EPSPs. J Neurosci 13:334-350.

Spitzer M, Neumann M (1996) Noise in models of neurological and psychiatric disorders. Int J Neural Syst 7:355-361.

Stanzione P, Calabresi P, Mercuri N, Bernardi G (1984) Dopamine modulates CA1 hippocampal neurons by elevating the threshold for spike generation: an in vitro study. Neuroscience 13:1105-1116.

Stuart GJ, Dodt HU, Sakmann B (1993) Patch-clamp recordings from the soma and dendrites of neurons in brain slices using infrared video microscopy. Pflügers Arch 423:511-518.

Verma A, Moghaddam B (1996) NMDA receptor antagonists impair prefrontal cortex function as assessed via spatial delayed alternation performance in rats: modulation by dopamine. J Neurosci 16:373-379.

Vincent SL, Khan Y, Benes FM (1993) Cellular distribution of dopamine D1 and D2 receptors in rat medial prefrontal cortex. J Neurosci $13: 2551-2564$.

Williams GV, Goldman-Rakic PS (1995) Modulation of memory fields by dopamine D1 receptors in prefrontal cortex. Nature 376:572-576.

Yang CR, Mogenson GJ (1990) Dopaminergic modulation of cholinergic responses in rat medial prefrontal cortex: an electrophysiological study. Brain Res 524:271-281.

Yang CR, Seamans JK (1996) Dopamine D1 receptor actions in layers $\mathrm{V}$-VI rat prefrontal cortex neurons in vitro: modulation of dendriticsomatic signal integration. J Neurosci 16:1922-1935.

Yang CR, Seamans JK, Gorelova N (1996) Electrophysiological and morphological properties of layers V-VI principal pyramidal cells in rat prefrontal cortex in vitro. J Neurosci 16:1904-1921.

Yang CR, Seamans JK, Gorelova N (1997) Mechanisms of dopamine (DA) modulation of GABAergic inputs to rat layer V-VI pyramidal prefrontal cortical (PFC) neurons in vitro. Soc Neurosci Abstr 23:1771.

Zahrt J, Taylor JR, Mathew RG, Arnsten AFT (1997) Supranormal stimulation of D1 dopamine receptors in the rodent prefrontal cortex impairs spatial working memory performance. J Neurosci 17:8528-8535.

Zheng P, Bunney BS, Shi WX (1997) Electrophysiological characterization and effect of dopamine on visually identified non-pyramidal neurons in the prefrontal cortex. Soc Neurosci Abstr 23:1212. 